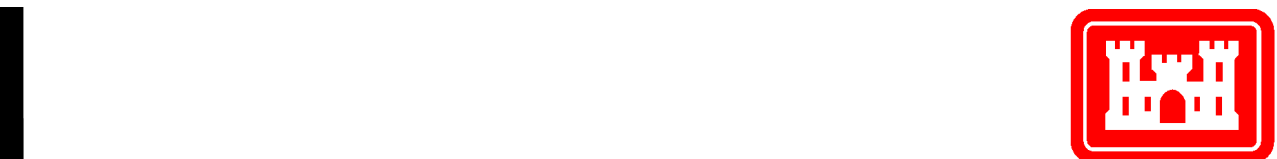

\title{
Management System for Fluid Storage Tanks at Fort Lewis, WA
}

Jearldine I. Northrup, Joyce C. Baird, Donald J. Schiller, and James F. Lee

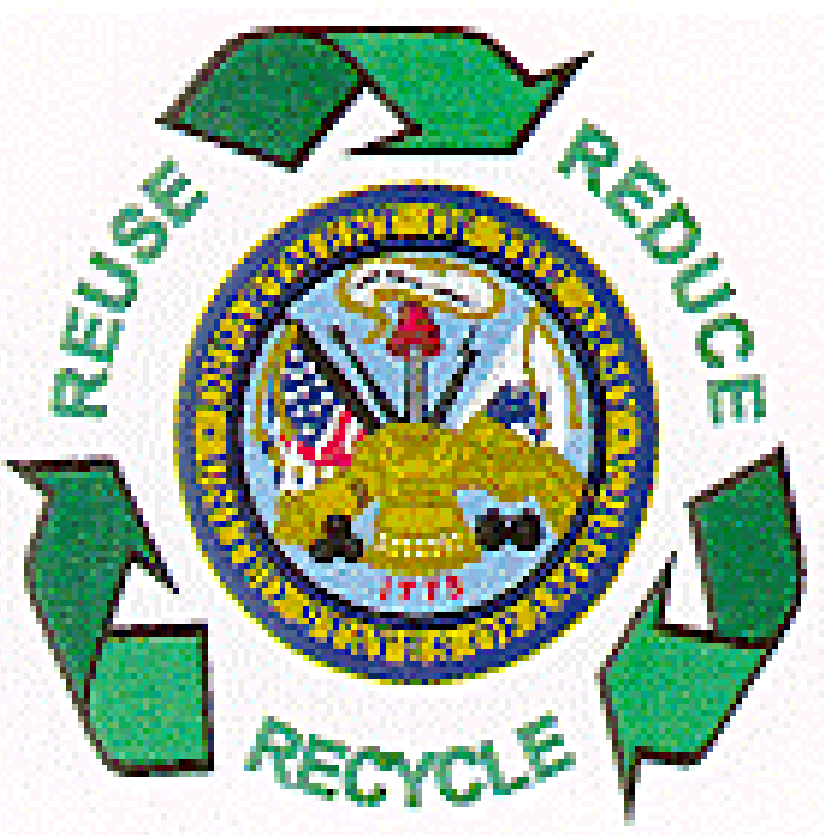

Fort Lewis Army Installation Fort Lewis, Washington 


\section{Foreword}

This study was conducted for Fort Lewis located in Washington, under Military Interdepartmental Purchase Request (MIPR) 0CCERL3012, "Remote UST Telemetry Project.” The technical monitor was James Lee, AFZH-DWS-RNB.

This work was performed by the Environmental Processes (CN-E) Branch, Construction Engineering Research Laboratory (CERL), the U.S. Army Engineer Research and Development Center (ERDC). Donald J. Schiller was project manager for MSE Technology Applications (MSE-TA), Butte, MT, which provided engineering design services and construction and installation of equipment. The CERL principal investigator was Jearldine I. Northrup. Dr. Ilker R. Adiguzel is Branch Chief, CN-E, and Dr. John Bandy is Chief, Installations Division, CN. The associated Technical Director was L. Michael Golish, CEERD-CVT. The ERDC technical editor was William J. Wolfe, Information Technology Laboratory. The Acting Director of CERL is William D. Goran.

CERL is an element of the U.S. Army Engineer Research and Development Center (ERDC), U.S. Army Corps of Engineers. The Director of ERDC is Dr. James R. Houston and the Commander is COL James S. Weller.

\section{DISCLAIMER}

The contents of this report are not to be used for advertising, publication, or promotional purposes. Citation of trade names does not constitute an official endorsement or approval of the use of such commercial products. All product names and trademarks cited are the property of their respective owners.

The findings of this report are not to be construed as an official Department of the Army position unless so designated by other authorized documents.

DESTROY THIS REPORT WHEN IT IS NO LONGER NEEDED. DO NOT RETURN IT TO THE ORIGINATOR. 


\section{Contents}

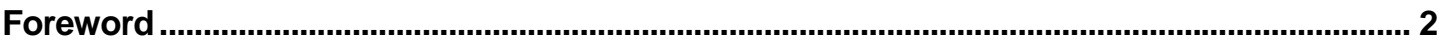

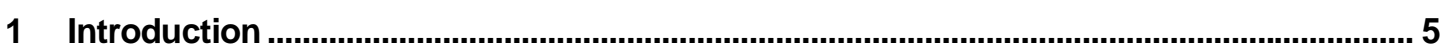

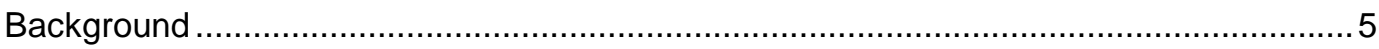

Fort Lewis Pollution Prevention Plan ..................................................................................

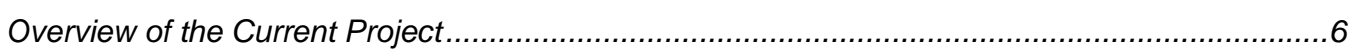

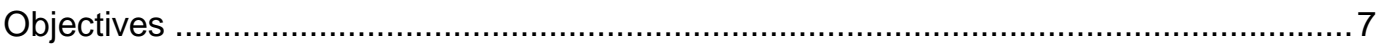

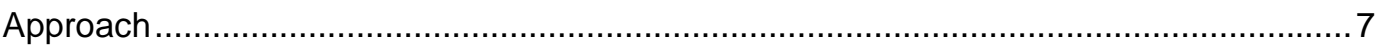

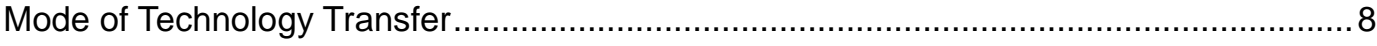

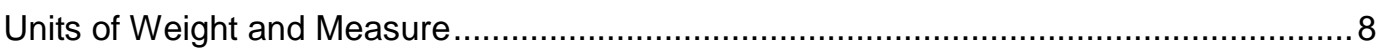

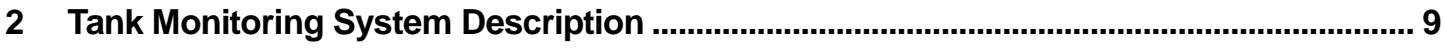

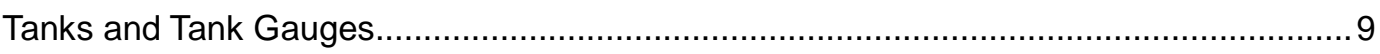

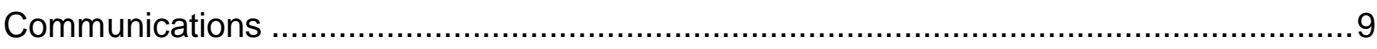

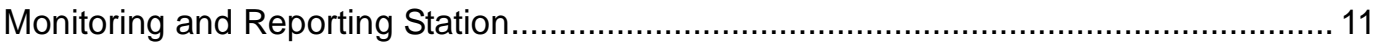

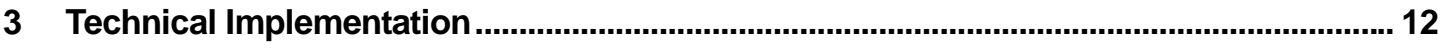

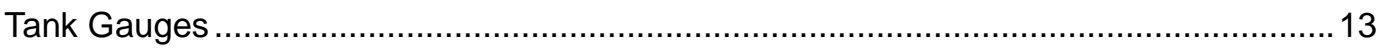

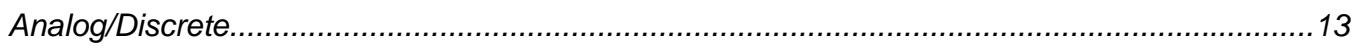

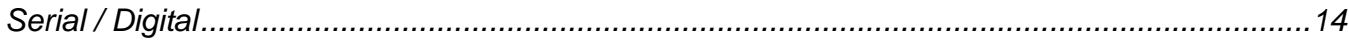

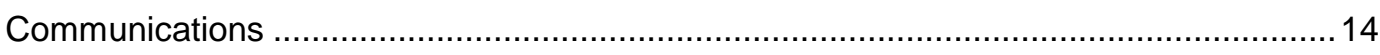

Telephone Line with Dial-Up Modem ........................................................................ 14

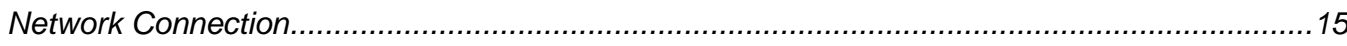

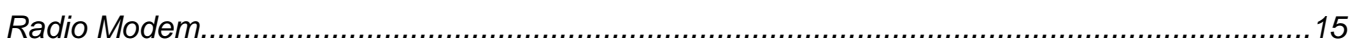

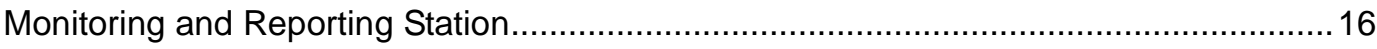

4 Summary

Appendix A: Available Tank Parameters .............................................................................. 18

Appendix B: State of Washington Summary of Requirements for USTs, Publication

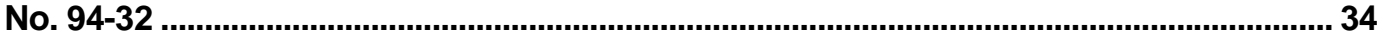

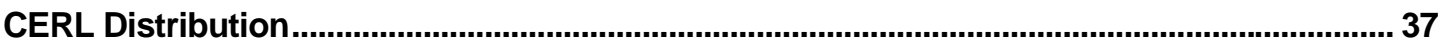

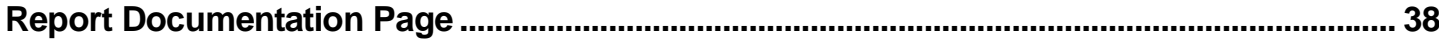





\section{Introduction}

\section{Background}

Fort Lewis Military Reservation is an 86,176 acre Army installation located in western Washington State. Fort Lewis' force structure includes I Corps Headquarters, which commands all Forces Command units at Fort Lewis. I Corps Headquarters conducts planning and also acts as a liaison with other active and reserve component units in the continental United States and active duty units located around the Pacific Rim and in Hawaii. Fort Lewis directly supports the Yakima Training Center, located in eastern Washington, and six Base Realignment and Closure (BRAC) installations in Washington and California.

Some of the military and nonmilitary organizations at Fort Lewis perform services and functions that require the use of hazardous substances and that generate hazardous waste. These services include the maintenance of over 4500 installation elements, including Fort Lewis' buildings and infrastructure (roads and utilities), and operation and maintenance (O\&M) of over 3000 vehicles and nearly 1500 pieces of equipment including aircraft, weapons systems, power generators, and communications equipment. Fort Lewis also houses a major hospital, several medical and dental clinics, printing and graphics facilities, materials storage warehouses, and crafts shops.

\section{Fort Lewis Pollution Prevention Plan}

The Fort Lewis Pollution Prevention Plan provides a specific plan and implementation schedule for the reduction of hazardous substance use and hazardous waste generation through selected pollution prevention opportunities. A formalized 5-year pollution prevention plan was completed in September 1992, with 1991 as the baseline year.

Fort Lewis planners have worked with regulators to ensure that the new plan meets State requirements, and also with the requirements of the Department of Defense and Executive Order 12856. The pollution prevention plan had baseline years of 1992, 1994, and 1996 and was submitted to Washington State Department of Ecology in September 1997. In September 1997, Fort Lewis received a Governor's Award for Outstanding Achievement in Pollution Prevention at the 
Washington State capitol. In recognition of the installation's steady improvements in implementing pollution prevention measures, Governor Gary Locke presented Lt. Gen. George A. Crocker with the Consistent Excellence in Pollution Prevention Award. A summary of Fort Lewis' Pollution Prevention Plan has been published to the World Wide Web (WWW) at URL:

http://128.174.5.51/denix/Public/News/Earthday97/Awards/lewis/fortlew.html\#Pollu

\section{Overview of the Current Project}

The U.S. Army Engineer Research and Development Center (ERDC), Construction Engineering Research Laboratory (CERL) and contractor MSE Technology Applications (MSE-TA) were tasked with electronically consolidating fluid storage tank information for underground storage tanks (USTs) and aboveground storage tanks (ASTs) at Fort Lewis. Fort Lewis has approximately 62 regulated and over 2000 unregulated tanks in service. A recent inspection of the regulated tanks resulted in the issuance of several notices of violation (NOVs). The Fort Lewis environmental office and public works has expressed a commitment to expediting the task of bringing all tanks within compliance. The installation of a centralized monitoring and alarming system for the fluid levels and leak detectors is part of the three-part program for bringing the tanks into both regulatory and legal compliance:

1. Proof of Concept Demonstration (POCD). This first task is to demonstrate an integrated system of limited scope. The demonstration included the functions of data communications, storage, alarming, and display. One regulated tank was connected by telephone line to a dedicated computer. This monitoring computer included installed monitoring software, which initiates a call several times a day to download and display the tank information. The system was also set up to allow the compliance officer to initiate the call manually at any time.

2. Connection of Regulated Tanks. This task will assess methods of connecting the regulated tanks to the monitoring system computer, and will provide data connection, storage, and display for as many of the remainder of the regulated tanks as funding allows.

3. Connection of the Unregulated Tanks. This task will demonstrate the existing system and solicit funding for connection of as many of the remaining unregulated tanks to the monitoring system as possible. 


\section{Objectives}

The overall objective of this work was to test and demonstrate the feasibility of an integrated monitoring and alarm system for USTs and ASTs at Fort Lewis, WA, and to install the system on all regulated tanks and as many unregulated tanks as possible.

The specific objective of this first part of the project was to conduct a proof-ofconcept demonstration designed to quickly provide a working "core" system on a limited number of tanks, which may be easily expanded to include more tanks.

This small system was also intended to be used as a demonstration platform to obtain support for future expansion, as well as to provide an opportunity to work out problems early before expansion begins.

\section{Approach}

This first stage of the project involved the following steps:

1. Regulated tanks that were not slated for decommissioning were connected to the monitoring system, as funding allowed.

2. Unregulated tanks were considered a second priority. (A common problem with the unregulated tanks is that they usually lacked functional tank gauges.)

3. Several methods were studied for communicating the tank data to the central monitoring computer, based on the requirements for connection. The most appropriate method to connect each tank was chosen from this "shopping list" of methods.

4. Each tank was assessed to determine the most practical method to connect it to the monitoring system computer. Many tanks were unique in their type of gauge interface and the availability of a network connection near the tank; appropriate interfaces were designed to match individual tanks.

5. Once a tank was connected to the monitoring computer, the addition of another tank to the system was simply a matter of copying a software module and completing another tank configuration.

6. The monitoring system was installed to easily support expansion to include any or all of the approximately 2000 or so remaining tanks at Fort Lewis. 


\section{Mode of Technology Transfer}

This work extends existing programs at Watervliet Arsenal and Corpus Christi Army Depot. Several concepts used here were proven in operation at those locations, and were refined for application at Fort Lewis. This report will be made available on the CERL and the Fort Lewis web sites.

The CERL web site address is: http://www.cecer.army.mil/

The Fort Lewis web site address is: http://www.lewis.army.mil/publicworks/Fuel.htm

\section{Units of Weight and Measure}

U.S. standard units of measure are used throughout this report. A table of conversion factors for Standard International (SI) units is provided below.

\begin{tabular}{|lll|}
\multicolumn{3}{|c|}{ SI conversion factors } \\
\hline $1 \mathrm{in.}$ & $=2.54 \mathrm{~cm}$ \\
$1 \mathrm{ft}$ & $=0.305 \mathrm{~m}$ \\
$1 \mathrm{yd}$ & $=0.9144 \mathrm{~m}$ \\
$1 \mathrm{sq} \mathrm{in.}$ & $=6.452 \mathrm{~cm}^{2}$ \\
$1 \mathrm{sq} \mathrm{ft}$ & $=0.093 \mathrm{~m}^{2}$ \\
$1 \mathrm{sq} \mathrm{yd}$ & $=0.836 \mathrm{~m}^{2}$ \\
$1 \mathrm{cu} \mathrm{in.}$ & $=16.39 \mathrm{~cm}^{3}$ \\
$1 \mathrm{cu} \mathrm{ft}$ & $=0.028 \mathrm{~m}^{3}$ \\
$1 \mathrm{cu} \mathrm{yd}$ & $=0.764 \mathrm{~m}^{3}$ \\
$1 \mathrm{gal}$ & $=3.78 \mathrm{~L}$ \\
$1 \mathrm{lb}$ & $=0.453 \mathrm{~kg}$ \\
$1 \mathrm{kip}$ & $=453 \mathrm{~kg}$ \\
$1 \mathrm{psi}$ & $=6.89 \mathrm{kPa}$ \\
${ }^{\circ} \mathrm{F}$ & $=\left({ }^{\circ} \mathrm{C} \times 1.8\right)+32$ \\
\hline
\end{tabular}




\section{Tank Monitoring System Description}

The Fort Lewis tank monitoring system has three subsystems: (1) Tanks and Tank Gauges, (2) Communications, and (3) Monitoring and Reporting Station. The following sections describe the three subsystems.

\section{Tanks and Tank Gauges}

The tank gauges on regulated tanks have strict regulatory requirements for installation and maintenance, and were determined to be outside the scope of this project. It was assumed that the gauges were, or soon would be, brought up to code to support effective monitoring and alarming.

The gauges for most of the regulated tanks were quite sophisticated systems that were able to monitor many tank parameters important to regulators. The vendors for the tank gauges to be installed are Veeder Root TLS-350, Ronan X76LVCS, and Petrosonic III. Appendix A gives vendor contact information and lists the available parameters for the Veeder Root TLS-350 gauge system.

The three gauge vendors above supply communications options that can be delivered with the unit, or installed later. These options are Standard RS-232 port, or telephone modem.

\section{Communications}

The communications link between tanks and the monitoring computer was designed based on the type of tank gauge, and proximity of the tank gauge to normal communications channels. A communications survey was conducted for each regulated tank to produce a working table (Figure 1 shows an example), to be used as the basis for the design. 


\begin{tabular}{|c|c|c|c|c|c|c|c|c|c|c|c|}
\hline $\begin{array}{c}\text { Facility Owner } \\
\text { (user level) }\end{array}$ & $\begin{array}{r}\text { Guage } \\
\text { Monitoring } \\
\text { System }\end{array}$ & $\begin{array}{l}\text { Building } \\
\text { Number }\end{array}$ & $\begin{array}{l}\text { Additional } \\
\text { location } \\
\text { information }\end{array}$ & $\begin{array}{c}\text { Tanks at } \\
\text { site }\end{array}$ & $\begin{array}{l}\text { Facility } \\
\text { Type }\end{array}$ & $\begin{array}{l}\text { Proposed } \\
\text { Status }\end{array}$ & $\begin{array}{c}\text { Numbers/ Tank } \\
\text { Capacity (in } \\
\text { gallons) }\end{array}$ & $\mid \begin{array}{ll}\text { Has } & A T G \\
\text { and } & \text { has } \\
\text { Com m m o }\end{array}$ & $\begin{array}{l}\text { Needs } \\
\text { A TG and } \\
\text { Commo }\end{array}$ & $\begin{array}{l}\text { Needs } \\
\text { Commo } \\
\text { only }\end{array}$ & $\begin{array}{l}\text { Needs } \\
\text { ATG only }\end{array}$ \\
\hline $\begin{array}{r}528 \text { th Quartermaster } \\
\text { Bulk Site }\end{array}$ & $\begin{array}{r}\text { ENCOMPASS } \\
\text { Arizona Equipment } \\
\end{array}$ & 3477 & Gray Arm y Airfield & 2 & aviation & active & $\begin{array}{l}3477-1(20,000) \\
3477-2(20,000)\end{array}$ & 2 & & & \\
\hline $\begin{array}{r}528 \text { th Quarterm aster } \\
\text { Bulk Site }\end{array}$ & $\begin{array}{r}\text { VeederRoot } \\
\text { TLS-350 }\end{array}$ & 3138 & Main Post & 4 & bulk & active & $\begin{array}{c}3138-6(25,000) \\
3138-7(10,000) \\
3138-8(5,000)\end{array}$ & 4 & & & \\
\hline $\begin{array}{r}\text { 528th Quartermaster } \\
\text { Bulk Site } \\
\end{array}$ & $\begin{array}{r}\text { VeederRoot } \\
\text { TLS-350 }\end{array}$ & 9635 & Logistics Center & 5 & bulk & active & $\begin{array}{l}9635-4(20,298) \\
9635-5(12,217) \\
9635-6(6,099) \\
96355-7(6,099)\end{array}$ & 5 & & & \\
\hline $\begin{array}{r}24 \text { th Quartermaster } \\
\text { Bulk Site } \\
\end{array}$ & $\begin{array}{r}\text { VeederRoot } \\
\text { TLS-350 } \\
\end{array}$ & 11 В 50 & North Fort & 3 & bulk & active & $\begin{array}{l}11 \mathrm{~B} 50-4(20,000) \\
11 \mathrm{~B} 50-5(20,000)\end{array}$ & 3 & & & \\
\hline AAFES Retail & $\begin{array}{r}\text { VeederRoot } \\
\text { TLS-350 } \\
\end{array}$ & 2407 & Stryker Shoppette & 3 & commercial & active & $\begin{array}{l}2407-6(12,000) \\
2407-7(12,000)\end{array}$ & 3 & & & \\
\hline AAFES Retail & $\begin{array}{r}\text { PETROSONIC III/ } \\
\text { Red Jacket }\end{array}$ & 6038 & Gateway Shoppette & 4 & commercial & active & $\begin{array}{l}6038-2(10,000) \\
6038-3(10,000) \\
6038-4(10,000)\end{array}$ & 4 & & & \\
\hline AAFES Retail & $\begin{array}{r}\text { VeederRoot } \\
\text { TLS-350R }\end{array}$ & 9052 & Madigan Shoppette & 3 & commercial & active & $\begin{array}{l}9052-1(12,000) \\
9052-2(12,000) \\
9052-3(12,000)\end{array}$ & 3 & & & \\
\hline $\mathrm{PW}$ & $\begin{array}{r}\text { Veederroot } \\
\text { TLS-350R } \\
\end{array}$ & 2051 & Main Post & 2 & fuel point & active & $\begin{array}{l}2051-4(15,000) \\
2051-5(15,000)\end{array}$ & 2 & & & \\
\hline DPCA & Ronan X76LVCS & 8981 & $\begin{array}{r}\text { American Lakel } \\
\text { North Fort }\end{array}$ & 2 & $\mathrm{marina}$ & active & $\begin{array}{l}8981-1(1,000) \\
8981-2(1,000)\end{array}$ & 2 & & & \\
\hline DPCA & None & 3205 & Gray Arm y Airfield & 1 & aviation & active & $3205-4(12,000)$ & & 1 & & \\
\hline $1 \mathrm{st} \mathrm{SFG}$ & None & 9145 & Main Post & 2 & fuel point & active & $9145-2(10,000)$ & & 2 & & \\
\hline 29 th STG & None & 3381 & Main Post & 1 & fuelpoint & active & $3381-1(20,000)$ & & & & \\
\hline 864 th ENG & None & 3392 & Main Post & 3 & fuel point & active & $\begin{array}{c}3392-2(20,000) \\
3392-3(500)\end{array}$ & & & & 3 \\
\hline $\begin{array}{r}\text { Directorate of } \\
\text { Logistics }\end{array}$ & None & $9580(9595)$ & Logistics Center & 3 & fuel point & active & $\begin{array}{c}9580-9(4,000) \\
9580-10(10,000)\end{array}$ & & 3 & & \\
\hline 1115th STG/PW & None & 2003 & Main Post & 1 & generator & active & $2003-3(300)$ & & & & \\
\hline Corps $\mathrm{HQ}$ & None & 2025 & Main Post & 2 & generator & active & $\begin{array}{l}2025-(1,000) \\
2025-(2,500)\end{array}$ & & & & 2 \\
\hline MAMC & Nonel & 9040 & $\begin{array}{l}\text { Madigan Army } \\
\text { Medical Center }\end{array}$ & 2 & generator & active & $\begin{array}{l}9040-1(40,000) \\
9040-2(40,000)\end{array}$ & & & & $2+2>$ \\
\hline DOLIPW & None & 9500 & Cannibalization point & 1 & generator & active & $9500-2(300)$ & & & & \\
\hline $\begin{array}{l}\text { Treatment Plant/PW } \\
\end{array}$ & None & $7500(7509)$ & Solo Point & 1 & generator & active & $7500-1(1,000)$ & & & & \\
\hline MAMC/PW & None & $9580(9576)$ & Logistics Center & 1 & generator & active & $9580-7(1,000)$ & & & & \\
\hline 1st SFG/PW & $\begin{array}{l}\text { None } \\
\text { None }\end{array}$ & $\frac{9190}{3850}$ & $\begin{array}{r}\text { Main Post } \\
\text { Boiler Plant }\end{array}$ & 1 & $\begin{array}{r}\text { generar } \\
\text { (Non- } \\
\text { Regulated) } \\
\text { generator }\end{array}$ & $\begin{array}{r}\text { active } \\
\text { close }(\text { dem o) }\end{array}$ & $\begin{array}{c}9190(1,000) \\
3850-2(1,000)\end{array}$ & & & & \\
\hline $\mathrm{PW}$ & None & 4535 & $\begin{array}{l}\text { North Fort/ Outfall } \\
\text { vic. Paint Ball Area }\end{array}$ & 2 & $\begin{array}{r}\text { skimmer } \\
\text { (Non- } \\
\text { Regulated) } \\
\end{array}$ & active & & & & & \\
\hline $\mathrm{PW}$ & None & PO 1407 & $\begin{array}{l}\text { Main Post/ Outfall } \\
\text { vic. Post Laundry }\end{array}$ & 1 & $\begin{array}{r}\text { (Non- } \\
\text { Regulated) } \\
\end{array}$ & active & & & & & \\
\hline PW & None & vic. 3916 & $\begin{array}{r}\text { Main Post vic. } 168 \mathrm{th} \\
\mathrm{EN} \\
\end{array}$ & 1 & $\begin{array}{r}\text { SkImmer } \\
\text { (Non- } \\
\text { Regulated) } \\
\end{array}$ & active & & & & & \\
\hline $\mathrm{PW}$ & None & vic. 3392 & Main Post vic. 864th & 2 & $\begin{array}{r}\text { (Non- } \\
\text { Regulated) }\end{array}$ & active & & & & & \\
\hline
\end{tabular}


Three communications methods were evaluated for each tank:

1. Telephone Line Connection. The telephone connection is made through a nearby phone line. This method was selected for tanks with installed Veeder-Root and Ronan tank gauging systems that had modem options available.

2. Network Connection. The network connection is made through a nearby Ethernet local area network (LAN) fiber optic cable. Interface electronics would be installed to connect the tank gauge to an addressable node on the fiber-optic LAN.

3. Radio Connection. The radio connection is made through a radio communications hub located near the monitoring computer, or at a central location within the facility to minimize transmission distances.

\section{Monitoring and Reporting Station}

The monitoring and reporting station is the "heart" of the system. It consists of a personal computer with a tank status and alarming display. This computer resides on the desk of the compliance officer in Public Works directorate.

Tank levels and alarm status are displayed on several monitoring screens developed and installed on commercial off-the-shelf software (COTS). 


\section{Technical Implementation}

Several methods can be used to bring USTs or ASTs under compliance:

- decommissioning the tank by removal or inerting in place

- replacing or upgrading the tank and/or gauging system to allow support of current regulations

- installing remote instrumentation to provide close monitoring of leaks, spills, overfills, or unauthorized dumping into a tank.

ASTs were included in this project because of a number of ASTs on site that pose an environmental risk.

The compliance method used at Fort Lewis for each tank was based on the evaluation of many factors, and was subject to Washington State Underground Storage Tank Regulations (Chapter 173-360 WAC). A summary of relevant portions of this regulation, taken from Washington State Publication \# 94-32, Summary of Requirements for Underground Storage Tanks, is included as Appendix B to this report. Many underground storage tanks were decommissioned, and this released some funding for a smaller number tanks that were more vital to the mission.

Tanks used to store heating oil on the premises for consumptive use are excluded from Federal UST regulations. However, State or Territorial regulatory agencies may regulate these tanks. The State of Washington does not regulate these tanks according to the information from this U.S. Environmental Protection Agency (USEPA) website:

\section{http://www.epa.gov/swerust1/heatoil.htm}

"Heating oil" includes several grades of petroleum fuel oils: No. 1, No. 2, No. 4light, No. 4-heavy, No. 5-light, No.5-heavy, No.6, Navy Special Fuel Oil, and Bunker C, and No.2 diesel fuel and kerosene (when used for heating purposes only).

The term "consumptive use" is not intended to apply to heating purposes only. The definition of consumptive use extends to any on-site use that may include 
heating, or generation of emergency power, steam, process heat, or electricity. The exclusion does not apply to tanks storing heating oil for resale.

The term "premises" is not limited to the building where the heating oil is stored; it includes any location on the property on which the building resides. Thus, centralized heating units using heating oil that serve more than one building on the same property would qualify for exclusion.

The urgency of the situation at Fort Lewis required that the evaluation and selection of the compliance method to be used for each tank was to parallel the design of the remote monitoring system. In this project, the more important tanks were considered in the first phase of the project, where "importance" was determined by size of the tank, risk of exposure, and importance to the mission. A prioritized list helped schedule the design effort. A number of tanks were removed before effort was wasted on communications scoping or other design tasks.

The following sections outline the technical implementation of the three subsystems of the Fort Lewis tank monitoring system.

\section{Tank Gauges}

A good tank gauging system on a regulated tank can satisfy the release protection requirement of the regulations. Gauges can monitor for leaks by using approved methods such as groundwater contamination monitoring (using vapor or water analysis), interstitial monitoring (double-wall tank integrity monitoring), or inventory control using precision level monitoring.

Most approved tank gauging systems on the market today are supplied with connections to allow remote monitoring. The connections are usually two classes: analog/discrete, or serial/digital.

\section{Analog/Discrete}

An analog/discrete connection will provide a signal that can connect to interface "black boxes" that can in turn connect to Ethernet networks, modems, or radios. The analog is usually what is called 4-20 mA, or current between 4 and 20 milliamps to represent the tank level from zero to 100 percent full. The "discrete" connection is an available relay contact that will close or open following an important tank alarm, indicating an event such as leak or overfill alarm. 


\section{Serial / Digital}

Serial/digital connections will provide an encoded stream of data over a pair of wires that can connect directly to modems or radios, or interface with Ethernet networks. The data communicate encoded tank status such as tank level in inches, or whether a leak alarm has occurred. Usually a remote system accesses a serial/digital gauge through an industry standard RS-232 port on the gauge, sends a request for the data, then waits for the response as a stream of data.

Tank gauges vary in sophistication from simple tank level monitors to full featured systems designed for use in gas stations, which also include water level gauging and automatic leak testing sequencing. For this project, the sophisticated Veeder Root TLS-350 systems were the first tank gauges connected. (These were the systems already in use on large fuel oil USTs.)

\section{Communications}

The data communication link connects to either the serial/digital or ana$\log /$ discrete port on the tank gauge and electronically transmits the required tank status to the central monitoring and reporting station. Three possible methods for obtaining data from the tank are:

1. Scheduled Automatic Update. In this case, a call is initiated from the monitoring and reporting station. (For example, a daily report may be programmed to callup at 4:00 a.m.)

2. Update on Demand. An update command may originate from the monitoring and reporting station. (For example, if a compliance officer requires an immediate report update, the system can generate current information on demand.)

3. Update Initiated from the Tank Gauge. (For example, an immediate data transmission would occur when the tank overfill alarm is activated.)

The following sections describe several data communications methods that were investigated for each tank installations.

\section{Telephone Line with Dial-Up Modem}

This method uses existing Fort Lewis dial-up telephone system lines and a modem at both the tank gauge and the monitoring and reporting stations to communicate tank data. The monitoring computer periodically dials each tank in rotation and downloads the current data. If the tank goes into alarm, a feature 
allows the tank gauge to automatically initiate an immediate call. At Fort Lewis, telephone line connections are less costly for many tank connections. Most tanks have a phone line nearby, and modem costs are minimal.

\section{Network Connection}

This method uses the existing Fort Lewis Ethernet network to connect the tank to the monitoring and reporting station. For this link, an interface device is connected between an Ethernet Hub port located near the tank and the tank gauge connection. This will allow direct electronic access to the tank data from any other port on the network, as long as the correct communications protocol is observed.

\section{Radio Modem}

This approach uses techniques similar to the telephone dial-up modem described above. The radio modem was considered primarily for the remote tank locations without phone line or network connections within practical wiring distance. For example, this method was practical for use with tank 3205, which is an underground aviation fuel tank located on an airfield quite removed from network or phone lines.

For radio modem communication the tank-monitoring computer is connected by a serial connection to a nearby radio master base station. Through this base station, the computer broadcasts a "request for data" signal that includes a unique tank address. All tanks with a remote terminal unit (RTU) radio receive the request simultaneously, but only the RTU with the matching address will answer with the tank data stream. All tanks are "polled" sequentially in this manner every minute, hour, or day as required. A master base station can serve from 20 to 50 RTUs, depending on polling speed and message size. The transmission rate selected for Fort Lewis is 1200 bits per second (bps), which is considered relatively slow in the modern computer communications world. However, the speed requirements for this project were low; $1200 \mathrm{bps}$ radio modems are adequate and significantly less expensive than faster communication devices.

The base station would use an omni-directional antenna to transmit and receive in all directions. The RTUs would use a yagi style antenna, which provides best communications signal strength when the yagi is pointing at the base station.

Two basic methods of radio communications were evaluated for Fort Lewis: 
1. Frequency Modulated (FM). In this application, FM radio communication operates in the nominal 150 Megahertz fixed frequency range. FM power levels would be $5 \mathrm{~W}$ for the RTUs and $25 \mathrm{~W}$ for the base station. The required FCC license can be obtained with the support of the radio vendor. The Directorate of Information Management (DOIM) is responsible for the coordination of radio frequency assignments, and would approve the request for frequency assignment.

2. Spread-Spectrum (SS) - SS radio communication rapidly changes frequencies in a preprogrammed sequence. Spread-spectrum requires no FCC licensing at low power levels, and is ideal for distances of less than approximately $2000 \mathrm{ft}$. This application was not well suited for use at a large installation such as Fort Lewis, where costly repeaters would likely be required to boost the effective distance of $\mathrm{SS}$ radio transmitters.

\section{Monitoring and Reporting Station}

The monitoring station consists of a personal computer and Microsoft ${ }^{\mathrm{TM}}$ Windows NT 4.0 operating system. CiTect ${ }^{\mathrm{TM}}$ brand Human Machine Interface (HMI) commercial off-the-shelf (COTS) software was installed to support graphical-based monitoring, alarming, trending, communications, and alarming/trending database. The monitoring station computer is located in offices of the public works directorate.

A tank monitoring software application was developed for the monitoring computer on the CiTect development platform. HMI software systems are typically very powerful tools for displaying information, or controlling a process. Numerous "screens" can be called up for viewing. Each screen can provide graphical display of various processes, functions, or areas of a facility.

The tank monitoring application has a "main" screen, which automatically loads and displays when the computer is turned on. This screen is a top-view bitmapped graphical map of the Fort Lewis site with all tanks represented at the respective locations on the map showing the tank level, and any alarms. Any individual tank icon can be "double-clicked" to invoke a more detailed display screen of the tank, which shows the vessel and status, various details of the tank, and the tank location. Also, alarm and level histories are stored and available for display and printing. This allows more careful diagnostics to determine if the tank has, or is developing a serious problem. 


\section{Summary}

This work has tested and successfully demonstrated the feasibility of an integrated monitoring and alarm system for USTs and ASTs at Fort Lewis, WA. One regulated tank was connected through a telephone connection to a dedicated computer. This monitoring computer included installed monitoring software, which initiates a call several times a day to download and display the tank information. The system was also set up to allow the compliance officer to initiate the call manually at any time.

This working "core" system, installed on a limited number of tanks, may be easily expanded to include more tanks. Once the needed support for future expansion is gained, both regulated and unregulated tanks may be linked to the monitoring system computer, to provide continuous data connection, storage, display, and alarms. 


\section{Appendix A: Available Tank Parameters}

Information about the Veeder Root TLS-350 is available through URL:

http://www.veeder-root.com/products/tls-350r_tech.shtml

Information about the Ronan X76LVCS is available through URL:

http://www.ronan.com/x76lvcs.htm

Information about the Petrosonic III is available (by clicking "ATG \& Leak Protection") through URL:

http://www.epa.gov/region07/programs/artd/ustbx/index2.htm

This appendix includes excerpts from Veeder Root TLS350 Gauge Operating Manual. Note that the TLS350 is an example of typical high-end tank gauging system - all parameters are accessible from dial-up modem and special access software. 
Table 5: In-Tank Leak Detection Displayed Messages

\begin{tabular}{|c|c|c|c|}
\hline ANNUAL TEST ALARM & Alarm & $\begin{array}{l}\text { An annual in-tank leak test has } \\
\text { not been successfully completed } \\
\text { within the preset time period. }\end{array}$ & $\begin{array}{l}\text { Rerun in-tank leak test. If second } \\
\text { test fails, call for service. }\end{array}$ \\
\hline ANNUAL TEST FAIL & Alarm & $\begin{array}{l}\text { In-tank leak }(0.10 \mathrm{gph}) \text { test } \\
\text { failed. }\end{array}$ & $\begin{array}{l}\text { Rerun in-tank leak test. If second } \\
\text { test fails, call for service. }\end{array}$ \\
\hline $\begin{array}{l}\text { ANNUAL TEST } \\
\text { WARNING }\end{array}$ & Alarm & $\begin{array}{l}\text { An anmual in-tank leak test has } \\
\text { not been successfully completed } \\
\text { within the preset time period. }\end{array}$ & $\begin{array}{l}\text { Rerun in-tank leak test. If second } \\
\text { test fails, call for service. }\end{array}$ \\
\hline $\begin{array}{l}\text { CSLD INCR RATE } \\
\text { WARN }\end{array}$ & Waming & $\begin{array}{l}\text { An excessive amount of thuid } \\
\text { leaked into the tank during a lest } \\
\text { period. }\end{array}$ & $\begin{array}{l}\text { Call for service following the } \\
\text { procedures established for your } \\
\text { site. }\end{array}$ \\
\hline DELIVERY NEEDED & Waming & $\begin{array}{l}\text { Product level dropped below } \\
\text { preset limit. }\end{array}$ & Call for delivery. \\
\hline GROSS TEST FAIL* & Alarm & $\begin{array}{l}\text { In-tank leak ( } 3.0 \text { gph) test } \\
\text { lailed. }\end{array}$ & $\begin{array}{l}\text { Rerun in-lank leak test. If second } \\
\text { test fails, call for service. }\end{array}$ \\
\hline $\begin{array}{l}\text { HIGH PRODUCT } \\
\text { ALARM }\end{array}$ & Alarm & $\begin{array}{l}\text { Product level in tank rose above } \\
\text { preset limit. }\end{array}$ & $\begin{array}{l}\text { Do not allow additional delivery } \\
\text { until product is dispensed below } \\
\text { presel linnit. }\end{array}$ \\
\hline $\begin{array}{l}\text { HIGH WATER } \\
\text { WARNING }\end{array}$ & Warning & $\begin{array}{l}\text { Water detected in tank exceeds } \\
\text { preset limit. }\end{array}$ & Remove water from the lank. \\
\hline $\begin{array}{l}\text { INVALID FUEL LEVEL } \\
\text { (Mag probes only) }\end{array}$ & Alarm & $\begin{array}{l}\text { Fuel level dropped to a point } \\
\text { below the minimum detectable } \\
\text { level or only one float is present. }\end{array}$ & Cail for delivery. \\
\hline LEAK ALARM & Alarm & A static in-tank leak test failed. & Rerun in-tank leak test. \\
\hline $\begin{array}{l}\text { LOW PRODUCT } \\
\text { ALARM }\end{array}$ & Nlarm & $\begin{array}{l}\text { Tank level dropped below preset } \\
\text { limit. }\end{array}$ & Call for delivery. \\
\hline LOW TEMP WARNING & Warning & $\begin{array}{l}\text { Probe temperature drops below } \\
-4 \% \mathrm{~F} \text {. }\end{array}$ & $\begin{array}{l}\text { Probe retums to normal operation } \\
\text { after probe temperature rises } \\
\text { above } 0^{\circ} \mathrm{F} \text {. }\end{array}$ \\
\hline $\begin{array}{l}\text { MAX PRODUCT } \\
\text { ALARM* }\end{array}$ & Alarm & $\begin{array}{l}\text { Product level rose above presel } \\
\text { limit. }\end{array}$ & $\begin{array}{l}\text { Stop delivery. Do not allow } \\
\text { additional delivery until product } \\
\text { drops below preset limit. }\end{array}$ \\
\hline NO CSLD IDLE TIME & Warning & $\begin{array}{l}\text { System has not had enough idle } \\
\text { time over previous } 24 \text { hours to } \\
\text { run a statistical leak detection } \\
\text { test. }\end{array}$ & $\begin{array}{l}\text { Stop dispensing fuel from this } \\
\text { tank until CSLD test is complete. }\end{array}$ \\
\hline OVERFILL ALARM & Alarm & $\begin{array}{l}\text { Polential overflow of tank may } \\
\text { occur. }\end{array}$ & Stop delivery. Check for spillage. \\
\hline $\begin{array}{l}\text { PERIODIC TEST } \\
\text { ALARM }\end{array}$ & Alarm & $\begin{array}{l}\text { A periodic in-tank leak }(0.20 \\
\text { gph) test has not been } \\
\text { successfully completed within } \\
\text { the preset time period. }\end{array}$ & $\begin{array}{l}\text { Rerun in-tank leak test. If second } \\
\text { test fails, call for service. }\end{array}$ \\
\hline
\end{tabular}


Table 5: In-Tank Leak Detection Displayed Messages (Continued)

\begin{tabular}{|c|c|c|c|}
\hline PERIODIC TEST FAIL* & Alarm & $\begin{array}{l}\text { In-tank leak }(0.20 \mathrm{gph}) \text { test } \\
\text { failed. }\end{array}$ & $\begin{array}{l}\text { Rerun in-tank leak test. If second } \\
\text { test fails, call for service. }\end{array}$ \\
\hline PERIODIC TEST WARN & Waming & $\begin{array}{l}\text { A periodic in-tank leak test has } \\
\text { not been successfully completed } \\
\text { within the preset time period. }\end{array}$ & $\begin{array}{l}\text { Rerun in-tank leak test. If second } \\
\text { test fails, call lor service. }\end{array}$ \\
\hline PROBE OUT & $\Lambda$ larm & $\begin{array}{l}\text { Hardware failure - probe or } \\
\text { interconnecting wiring to } \\
\text { console. }\end{array}$ & Call for service. \\
\hline $\begin{array}{l}\text { SETUP DATA } \\
\text { WARNING }\end{array}$ & Warning & $\begin{array}{l}\text { System setup problem or probe } \\
\text { out on startup. }\end{array}$ & $\begin{array}{l}\text { Reenter tank setup for problem } \\
\text { lank or test probe on another } \\
\text { channel. }\end{array}$ \\
\hline SUDDEN LOSS ALARM & Nlarm & $\begin{array}{l}\text { System detects loss of fuel } \\
\text { during an idle period. }\end{array}$ & Check for gross leak. \\
\hline TANK TEST ACTIVE & Warning & In-tank leak test underway. & $\begin{array}{l}\text { Do not dispense fuel from this } \\
\text { tank until message disappears. }\end{array}$ \\
\hline TANK SIPHON BREAK & Warning & $\begin{array}{l}\text { Siphon break valve has shut } \\
\text { down manifold for tank test. }\end{array}$ & Clears when tank test completes. \\
\hline
\end{tabular}

Table 6: In-Tank Leak Detection Invalidation Criteria

\begin{tabular}{|c|c|c|}
\hline $\begin{array}{l}\text { Printout Message } \\
\text { (Not displayed) }\end{array}$ & Probable Cause & Action \\
\hline $\begin{array}{l}\text { RECENT DELIVERY } \\
\text { ERROR }\end{array}$ & $\begin{array}{l}\text { A delivery occurred during the leak } \\
\text { detect test or less than } 8 \text { hours before } \\
\text { beginning the leak detect test. }\end{array}$ & $\begin{array}{l}\text { Retest, waiting longer than } 8 \text { hours after } \\
\text { last delivery. }\end{array}$ \\
\hline LOW LEVEL TEST ERROR & Fuel level is too low during a tank test. & Need fuel delivery to raise fuel level. \\
\hline $\begin{array}{l}\text { FIRST LEAK PERIOD } \\
\text { ERROR }\end{array}$ & $\begin{array}{l}\text { System was unable to obtain enough } \\
\text { valid samples to start a leak test during } \\
\text { the first leak period (first half hour). }\end{array}$ & $\begin{array}{l}\text { Call for service following the procedures } \\
\text { established for your site. }\end{array}$ \\
\hline $\begin{array}{l}\text { LAST LEAK PERIOD } \\
\text { ERROR }\end{array}$ & $\begin{array}{l}\text { System was unable to obtain enough } \\
\text { valid samples to start a lcak test during } \\
\text { the last leak period (last half hour). }\end{array}$ & $\begin{array}{l}\text { Call for service following the procedures } \\
\text { established for your sile. }\end{array}$ \\
\hline $\begin{array}{l}\text { TEMPERATURE OUT OF } \\
\text { RANGE }\end{array}$ & $\begin{array}{l}\text { Temperature reading is below } 0^{\circ} \mathrm{F} \text { or } \\
\text { above } 100^{\circ} \mathrm{F} \text {. }\end{array}$ & $\begin{array}{l}\text { Wait for temperature to recnter the } \\
\text { probe's operating range. }\end{array}$ \\
\hline $\begin{array}{l}\text { TEMPERATURE CHANGE } \\
\text { TOO LARGE }\end{array}$ & $\begin{array}{l}\text { Fuel temperature changed by more than } \\
0.1 \text { degree per hour since the reference } \\
\text { period (the first hour of the test). }\end{array}$ & Retest. \\
\hline $\begin{array}{l}\text { CHANGE IN TANK } \\
\text { TEMPERATURE ZONE } \\
\text { (Magnetostrictive Probes } \\
\text { only) }\end{array}$ & $\begin{array}{l}\text { Fucl temperature changed by more than } \\
0.4 \text { degree per hour or the temperature } \\
\text { thermistor is covered. }\end{array}$ & $\begin{array}{l}\text { Retest. If the problem continues, call for } \\
\text { service following the procedures } \\
\text { established for your site. }\end{array}$ \\
\hline
\end{tabular}


Table 6: In-Tank Leak Detection Invalidation Criteria (Continued)

\begin{tabular}{|c|c|c|}
\hline $\begin{array}{l}\text { Printout Message } \\
\text { (Not displayed) }\end{array}$ & Probable Cause & Action \\
\hline $\begin{array}{l}\text { CHANGE IN HEAD } \\
\text { TEMPERATURE } \\
\text { (Magnetostrictive Probes } \\
\text { only) }\end{array}$ & $\begin{array}{l}\text { Temperature of probe electronics } \\
\text { changed too drastically. }\end{array}$ & Retest. \\
\hline LEAK TEST TOO SHORT & Longer test time needed. & $\begin{array}{l}\text { Retest. For manual test runs, allow } \\
\text { longer test time. For programmed test } \\
\text { runs, program a longer test time. }\end{array}$ \\
\hline $\begin{array}{l}\text { PERCENT VOLUME TOO } \\
\text { LOW } \\
\text { (Mag \& Probes only) }\end{array}$ & $\begin{array}{l}\text { Fuel level is below "LEAK MINIMUM } \\
\text { ANNUAL" percentage or LEAK } \\
\text { MINIMUM PERIODIC. }\end{array}$ & Call for delivery. \\
\hline $\begin{array}{l}\text { INVALID FUEL LEVEL } \\
\text { (Magnetostrictive Probes } \\
\text { only) }\end{array}$ & $\begin{array}{l}\text { Fuel level is too low, causing the fuel } \\
\text { and water floats to be too close } \\
\text { together. }\end{array}$ & Call for delivery. \\
\hline $\begin{array}{l}\text { PRODUCT LEVEL } \\
\text { INCREASE }\end{array}$ & $\begin{array}{l}\text { Fuel volume increased significantly } \\
\text { during the test. Tank is not thermally } \\
\text { stable or fuel is draining from lines } \\
\text { back into tank. }\end{array}$ & $\begin{array}{l}\text { Call for service following the procedures } \\
\text { established for your site. }\end{array}$ \\
\hline
\end{tabular}

Table 7: Liquid Sensor Status Indicators - Piping Sump, Steel or Fiberglass 'Tank Interstitial Sensors

\begin{tabular}{|l|l|l|l|}
\hline \multicolumn{1}{|c|}{ Display Message } & \multicolumn{1}{|c|}{$\begin{array}{c}\text { Front Panel } \\
\text { Indicator }\end{array}$} & \multicolumn{1}{|c|}{ Cause } & \multicolumn{1}{|c|}{ Action } \\
\hline \hline FUEL ALARM & Alarm & $\begin{array}{l}\text { An interstitial or piping sump } \\
\text { liquid sensor detects liquid in a } \\
\text { ank's interstitial space or piping } \\
\text { sump. }\end{array}$ & $\begin{array}{l}\text { Call for service following the } \\
\text { procedures established for your } \\
\text { site. }\end{array}$ \\
\hline $\begin{array}{l}\text { SENSOR OUT } \\
\text { ALARM }\end{array}$ & Alarm & $\begin{array}{l}\text { A sensor is disconnected or is not } \\
\text { functioning properly. }\end{array}$ & $\begin{array}{l}\text { Call for service following the } \\
\text { procedures established for your } \\
\text { sile. }\end{array}$ \\
\cline { 2 - 4 } & $\begin{array}{l}\text { Liquid sensor setup was } \\
\text { performed incorrectly. }\end{array}$ & $\begin{array}{l}\text { Recuter this liquid sensor's setup } \\
\text { values. }\end{array}$ \\
\hline
\end{tabular}


Table 8: $\quad$ Liquid Sensor Status Indicators - Normally Closed Sensors

\begin{tabular}{|l|l|l|l|}
\hline Display Message & \multicolumn{1}{|c|}{$\begin{array}{c}\text { Front Panel } \\
\text { Indicator }\end{array}$} & Cause & Action \\
\hline FUEL ALARM & Alarm & $\begin{array}{l}\text { An interstitial or piping sump liquid } \\
\text { sensor detects liquid in a tank's } \\
\text { interstitial space or piping sump. }\end{array}$ & $\begin{array}{l}\text { Call for service following the } \\
\text { procedures established for your } \\
\text { site. }\end{array}$ \\
\hline
\end{tabular}

Table 9: Liquid Status Sensor Indicators - Dual Float Differentiating (Hydrostatic) Sensor's

\begin{tabular}{|c|c|c|c|}
\hline Display Message & $\begin{array}{l}\text { Front Panel } \\
\text { Indicator }\end{array}$ & Cause & Action \\
\hline $\begin{array}{l}\text { HIGH LIQUID } \\
\text { ALARM }\end{array}$ & ヘlarm & $\begin{array}{l}\text { A sensor in a brine-lilled interstice } \\
\text { detects an increase in the brine level } \\
\text { increase. Liquid is entering the riser } \\
\text { pipe, or in a high groundwater area, } \\
\text { an outer wall rupture has occurred. }\end{array}$ & $\begin{array}{l}\text { Call for service following the } \\
\text { procedures established for your } \\
\text { site. }\end{array}$ \\
\hline $\begin{array}{l}\text { LOW LIQUID } \\
\text { ALARM }\end{array}$ & Warning & $\begin{array}{l}\text { A sensor in a brine-filled interstice } \\
\text { detects a decrease in the brine level. } \\
\wedge \text { hole is in the tank's inner wall, or } \\
\text { in low groundwater areas, a hole is } \\
\text { in the outer wall. }\end{array}$ & $\begin{array}{l}\text { Call for service following the } \\
\text { procedures established for your } \\
\text { site. }\end{array}$ \\
\hline $\begin{array}{l}\text { SENSOR OUT } \\
\text { ALARM }\end{array}$ & Alarm & $\begin{array}{l}\text { A sensor is disconnected or is not } \\
\text { functioning properly. }\end{array}$ & $\begin{array}{l}\text { Call for service following the } \\
\text { procedures established for your } \\
\text { site. }\end{array}$ \\
\hline
\end{tabular}

Table 10: Liquid Status Sensor Indicators

\begin{tabular}{|l|l|l|l|}
\hline \multicolumn{1}{|c|}{ Display Message } & \multicolumn{1}{|c|}{$\begin{array}{c}\text { Front Panel } \\
\text { Indicator }\end{array}$} & Cause & Action \\
\hline \hline Dual Float Discriminating Dispenser Pan and Containment Sump Sensors \\
\hline SHORT ALARM & Nlarm & $\begin{array}{l}\text { An internal short has occurred in the } \\
\text { sensor. }\end{array}$ & $\begin{array}{l}\text { Call for service following the proce- } \\
\text { dures established for your site. }\end{array}$ \\
\hline $\begin{array}{l}\text { HIGH LIQUID } \\
\text { ALARM }\end{array}$ & Alarm & $\begin{array}{l}\text { Liquid reached 8" on the dispenser } \\
\text { pan sensor or } 10 " \text { on the contain- } \\
\text { ment sump sensor. }\end{array}$ & $\begin{array}{l}\text { Immediately follow the alarm report- } \\
\text { ing procedures established for your } \\
\text { site. }\end{array}$ \\
\hline FUEL ALARM & Alarm & $\begin{array}{l}\text { Fuel is present in the area being } \\
\text { monitored by the sensor. }\end{array}$ & $\begin{array}{l}\text { lmmediately follow the alarm report- } \\
\text { ing procedures established for your } \\
\text { site. Refer to the System Setup Man- } \\
\text { ual for more information on recover- } \\
\text { ing from an alarm due to leak or spill } \\
\text { in the containment area. }\end{array}$ \\
\hline
\end{tabular}


Table 10: Liquid Status Sensor Indicators (Continued)

\begin{tabular}{|c|c|c|c|}
\hline Display Message & $\begin{array}{l}\text { Front Panel } \\
\text { Indicator }\end{array}$ & Cause & Action \\
\hline $\begin{array}{l}\text { LIQUID } \\
\text { WARNING }\end{array}$ & Warning & $\begin{array}{l}\text { Liquid reached l" on the dispenser } \\
\text { pan or containment sump sensors. }\end{array}$ & $\begin{array}{l}\text { Immediately follow the alam report- } \\
\text { ing procedures established for your } \\
\text { site. }\end{array}$ \\
\hline \multirow[t]{2}{*}{$\begin{array}{l}\text { SENSOR OUT } \\
\text { ALARM }\end{array}$} & \multirow[t]{2}{*}{ Alarm } & $\begin{array}{l}\text { The sensor is disconnected or is not } \\
\text { functioning properly. }\end{array}$ & $\begin{array}{l}\text { Sensor problem must be corrected or } \\
\text { sensor replaced. Call for service by } \\
\text { following the procedures established } \\
\text { for your site. }\end{array}$ \\
\hline & & $\begin{array}{l}\text { Licuid sensor setup was performed } \\
\text { incorrectly. }\end{array}$ & $\begin{array}{l}\text { Reenter this liquid sensor's setup val- } \\
\text { ues. }\end{array}$ \\
\hline \multicolumn{4}{|c|}{ Oil/Water Separator Sensor } \\
\hline SHORT ALARM & Alarm & $\begin{array}{l}\text { An internal short has occurred in the } \\
\text { sensor. }\end{array}$ & $\begin{array}{l}\text { Call for service following the proce- } \\
\text { dures cslablished for your site. }\end{array}$ \\
\hline FUEL ALARM & Alarm & $\begin{array}{l}\text { Sensor indicates oil products vol- } \\
\text { ume has reached maximum. }\end{array}$ & $\begin{array}{l}\text { Excess of oil products MUST pumped } \\
\text { out IMMEDIATELY to prevent acei- } \\
\text { dental oil discharge. Tank MUST be } \\
\text { filled up with water for proper lank } \\
\text { and sensor operation. }\end{array}$ \\
\hline LIQUID WARNING & Warning & $\begin{array}{l}\text { Sensor indicates increasing oil } \\
\text { products volume. }\end{array}$ & $\begin{array}{l}\text { Oil pump-out to be seheduled. Oil } \\
\text { products to be pumped out before } \\
\text { "FULL } \triangle L A R M \text { " message dis- } \\
\text { played. Tank MUST be filled up, with } \\
\text { water for proper tank and sensor oper- } \\
\text { ation. }\end{array}$ \\
\hline \multirow[t]{2}{*}{$\begin{array}{l}\text { SENSOR OUT } \\
\text { ALARM }\end{array}$} & \multirow[t]{2}{*}{ Alarm } & $\begin{array}{l}\text { The sensor is disconnected or is not } \\
\text { functioning properly. }\end{array}$ & $\begin{array}{l}\text { Sensor problem must be corrected or } \\
\text { sensor replaced. Call for service by } \\
\text { following the procedures established } \\
\text { for your site. }\end{array}$ \\
\hline & & $\begin{array}{l}\text { Liquid sensor setup was performed } \\
\text { incorrectly. }\end{array}$ & $\begin{array}{l}\text { Reenter this liquid sensor's setup val- } \\
\text { ues. }\end{array}$ \\
\hline
\end{tabular}


Table 11: Vapor Sensor Stat us Indicators

\begin{tabular}{|l|l|l|l|}
\hline \multicolumn{1}{|c|}{ Display Message } & \multicolumn{1}{|c|}{$\begin{array}{c}\text { Front Panel } \\
\text { Indicator }\end{array}$} & Caruse & Action \\
\hline FUEL ALARM & Alarm & $\begin{array}{l}\text { A vapor sensor in an observation } \\
\text { well detects fucl vapor levels that } \\
\text { excecd the vapor alarm threshold } \\
\text { set for that well. }\end{array}$ & $\begin{array}{l}\text { Call for service following the } \\
\text { procedures established for your } \\
\text { site. }\end{array}$ \\
\hline WATER ALARM & Warning & $\begin{array}{l}\text { A vapor sensor is immersed in } \\
\text { water and is incapable of detecting } \\
\text { fuel vapors. }\end{array}$ & $\begin{array}{l}\text { Call for service following the } \\
\text { procedures cstablished for your } \\
\text { site. }\end{array}$ \\
\hline $\begin{array}{l}\text { SENSOR OUT } \\
\text { ALARM }\end{array}$ & Alarm & $\begin{array}{l}\text { A vapor sensor is disconnected or is } \\
\text { not functioning properly. }\end{array}$ & $\begin{array}{l}\text { Call for service following the } \\
\text { procedures cstablished for your } \\
\text { site. }\end{array}$ \\
\hline SHORT ALARM & Alarm & $\begin{array}{l}\text { An internal short has occurred in a } \\
\text { vapor sensor. }\end{array}$ & $\begin{array}{l}\text { Call for service following the } \\
\text { procedures cstablished for your } \\
\text { site. }\end{array}$ \\
\hline
\end{tabular}

Table 12: Receiver Status Indicator

\begin{tabular}{|c|c|c|c|}
\hline Display Message & $\begin{array}{c}\text { Front Panel } \\
\text { lndicator }\end{array}$ & Cause & Action \\
\hline AUTODIAL FAILURE & Alarm & $\begin{array}{l}\text { System failed to connect to a } \\
\text { remote receiver after "n" tries. }\end{array}$ & Check remote receiver. \\
\hline
\end{tabular}

Table 13: Pressurized Line Leak Detector Status Indicators

\begin{tabular}{|c|c|c|c|}
\hline Display Message & $\begin{array}{l}\text { Front Panel } \\
\text { Indicator }\end{array}$ & Cause & Action \\
\hline $\begin{array}{l}\text { ANNUAL LINE } \\
\text { FAIL }\end{array}$ & Alarm & $\begin{array}{l}0.10 \text { gph line test failure. } \\
\text { Dispensing halts while the } \\
\text { alarm is active (only if system } \\
\text { was programmed to shut down } \\
\text { for a } 0.10 \text { gph leak). }\end{array}$ & $\begin{array}{l}\text { Furn ofl dispensing nozzles. } \\
\text { Follow the procedures in this } \\
\text { mamual to verify the leak. } \Lambda \\
0.10 \text { gph test must pass to clear } \\
\text { this alatm. }\end{array}$ \\
\hline $\begin{array}{l}\text { CONTINUOUS } \\
\text { PUMP ALARM }\end{array}$ & Alarm & $\begin{array}{l}\text { Pump has been rumning for } 16 \\
\text { hours. }\end{array}$ & $\begin{array}{l}\text { This alarm shuts down the line. } \\
\text { Call for service following the } \\
\text { procedures established for your } \\
\text { site. }\end{array}$ \\
\hline
\end{tabular}


Table 13: $\quad$ Pressurized Line Leak Detector Status Indicators (Continued)

\begin{tabular}{|c|c|c|c|}
\hline Display Message & $\begin{array}{l}\text { Front Panel } \\
\text { Indicator }\end{array}$ & Cause & Action \\
\hline $\begin{array}{l}\text { CONTINUOUS } \\
\text { PUMP WRN }\end{array}$ & Warning & $\begin{array}{l}\text { Pump has been running for } 8 \\
\text { hours. }\end{array}$ & Turn off the dispenser to reset. \\
\hline GROSS LINE FAIL & Alarm & $\begin{array}{l}3.0 \text { gph line test failure. } \\
\text { Dispensing halts while the } \\
\text { alarm is active. }\end{array}$ & $\begin{array}{l}\text { Tum of dispensing nozzles. } \\
\text { Sec the Leak Veritication } \\
\text { Procedure on page } 159 \text { to verify } \\
\text { the leak. }\end{array}$ \\
\hline $\begin{array}{l}\text { HIGH PRESSURE } \\
\text { ALARM }\end{array}$ & Alarm & $\begin{array}{l}\text { Line leak detector components } \\
\text { are not functioning properly } \\
\text { (shuts off pump). }\end{array}$ & $\begin{array}{l}\text { Call for service following the } \\
\text { procedures established for your } \\
\text { site. }\end{array}$ \\
\hline $\begin{array}{l}\text { HIGH PRESSURE } \\
\text { WARN }\end{array}$ & Warning & $\begin{array}{l}\text { Pressure relief components in } \\
\text { the line are not functioning } \\
\text { properly. }\end{array}$ & $\begin{array}{l}\text { Call for service following the } \\
\text { procedures established for your } \\
\text { site. }\end{array}$ \\
\hline $\begin{array}{l}\text { LOW PRESSURE } \\
\text { ALARM }\end{array}$ & Alarm & $\begin{array}{l}\text { Low pump dispense pressure is } \\
\text { detected during a dispense. } \\
\text { Dispensing halts. }\end{array}$ & $\begin{array}{l}\text { The next handle up will restart } \\
\text { the pump. }\end{array}$ \\
\hline $\begin{array}{l}\text { PERIODIC LINE } \\
\text { FAIL }\end{array}$ & Alarm & $\begin{array}{l}0.20 \text { gph line test failure. } \\
\text { Dispensing halts while the } \\
\text { alarm is active (only if system } \\
\text { was programmed to shut down } \\
\text { for a } 0.20 \mathrm{gph} \text { leak). }\end{array}$ & $\begin{array}{l}\text { Turn off dispensing nozzles. } \\
\text { See the Leak Verification } \\
\text { Procedure on page } 159 \text { to verify } \\
\text { the leak. }\end{array}$ \\
\hline $\begin{array}{l}\text { PLLD } \\
\text { PERIODIC WARN }\end{array}$ & Warning & $\begin{array}{l}\text { System fails to perform a } \\
\text { periodic test }(0.20 \mathrm{gph}) \text { in the } \\
\text { programmed number of days. } \\
\text { The number of days is set up in } \\
\text { "Periodic Test Warnings," } \\
\text { System Setup menu. Dispensing } \\
\text { halts. } A 0.20 \text { gph test must pass } \\
\text { to clear the alarm. }\end{array}$ & $\begin{array}{l}0.20 \text { gph test must pass to clear } \\
\text { the alarm. } \\
\text { See the Leak Verification } \\
\text { Procedure on page } 159 \text { to verify } \\
\text { the leak. }\end{array}$ \\
\hline $\begin{array}{l}\text { PLLD } \\
\text { PERIODIC ALARM }\end{array}$ & Nlarm & $\begin{array}{l}\text { System fails to perform a } \\
\text { periodic test }(0.20 \text { gph }) \text { in the } \\
\text { programmed number of days. } \\
\text { The number of days is set up in } \\
\text { "Periodic Test Alarms," System } \\
\text { Setup menu. Dispensing halts. } \\
\text { A } 0.20 \text { gph test must pass to } \\
\text { clear the alarm. }\end{array}$ & $\begin{array}{l}0.20 \text { gph test must pass to clear } \\
\text { the alarm. } \\
\text { Sec the Leak Verification } \\
\text { Procedure on page } 159 \text { to verify } \\
\text { the leak. }\end{array}$ \\
\hline $\begin{array}{l}\text { PLLD OPEN } \\
\text { ALARM }\end{array}$ & Alarm & $\begin{array}{l}\text { Pressure sensor reading is less } \\
\text { than }-3 \text { psi. Only tested while } \\
\text { the pump is running. } \\
\text { Dispensing halts. If this alarm is } \\
\text { triggered while a short alam is } \\
\text { active, the short alarm will be } \\
\text { cleared. }\end{array}$ & $\begin{array}{l}3.0 \text { gph test must pass to clear } \\
\text { the alarm. } \\
\text { Call for service following the } \\
\text { procedures established for your } \\
\text { site. }\end{array}$ \\
\hline
\end{tabular}


Table 13: $\quad$ Pressurized Line Leak Detector Status Indicators (Continued)

\begin{tabular}{|l|l|l|l|}
\hline \multicolumn{1}{|c|}{ Display Message } & \multicolumn{1}{|c|}{$\begin{array}{c}\text { Front Panel } \\
\text { Indicator }\end{array}$} & \multicolumn{1}{|c|}{ Cause } & Action \\
\hline $\begin{array}{l}\text { PLLD SHUTDOWN } \\
\text { ALARM }\end{array}$ & Alarm & $\begin{array}{l}\text { System shut down line because } \\
\text { of failed line leak test. }\end{array}$ & $\begin{array}{l}\text { See above PL LD alarms for } \\
\text { corrective action. }\end{array}$ \\
\hline $\begin{array}{l}\text { PRECISION LINE } \\
\text { FAIL }\end{array}$ & Alarm & $\begin{array}{l}0.20 \text { gph line test failure. } \\
\text { Dispensing halts while the } \\
\text { alarm is active (only if system } \\
\text { was programmed to shut down } \\
\text { for a } 0.20 \text { gph leak) }\end{array}$ & $\begin{array}{l}\text { Turn off dispensing nozzles. } \\
\text { Procedure on page } 159 \text { to verify } \\
\text { the leak. }\end{array}$ \\
\hline SHORT ALARM & Alarm & $\begin{array}{l}\text { Possibly due to incorrect } \\
\text { wiring, bad transducer, or stuck } \\
\text { relay. }\end{array}$ & $\begin{array}{l}\text { Call for service following the } \\
\text { procedures established for your } \\
\text { site. }\end{array}$ \\
\hline
\end{tabular}

Table 14: Wireless Pressurized Line Leak Detector Status Indicators

\begin{tabular}{|c|c|c|c|}
\hline Display Message & $\begin{array}{l}\text { Front Panel } \\
\text { Indicator }\end{array}$ & Cause & Action \\
\hline ANNUAL ALM & Alarm & $\begin{array}{l}0.10 \text { gph line test lailure. } \\
\text { Dispensing halts while the } \\
\text { alarm is active (only if system } \\
\text { was programmed to shut down } \\
\text { for a } 0.10 \text { gph leak). }\end{array}$ & $\begin{array}{l}\text { Turn off dispensing nozzles. } \\
\text { Follow the procedures in this } \\
\text { manual to verify the leak. A } \\
0.10 \text { gph test must pass to clear } \\
\text { this alarm. }\end{array}$ \\
\hline $\begin{array}{l}\text { ANNUAL LINE } \\
\text { FAIL }\end{array}$ & Alarm & $\begin{array}{l}0.10 \text { gph line test failure. } \\
\text { Dispensing halts while the } \\
\text { alarm is active (only if system } \\
\text { was programmed to shut down } \\
\text { for a } 0.10 \text { gph leak). }\end{array}$ & $\begin{array}{l}\text { Turn off dispensing nozzles. } \\
\text { Follow the procedures in this } \\
\text { manual to verify the leak. A } \\
0.10 \text { gph test must pass to clear } \\
\text { this alarm. }\end{array}$ \\
\hline $\begin{array}{l}\text { CONTINUOUS } \\
\text { PUMP ALARM }\end{array}$ & Alarm & $\begin{array}{l}\text { Pump has been running for } 16 \\
\text { hours. }\end{array}$ & $\begin{array}{l}\text { This alarm shuts down the line. } \\
\text { Call for service following the } \\
\text { procedures established for your } \\
\text { site. }\end{array}$ \\
\hline $\begin{array}{l}\text { CONTINUOUS } \\
\text { PUMP WRN }\end{array}$ & Warning & $\begin{array}{l}\text { Pump has been rumning for } 8 \\
\text { hours. }\end{array}$ & Turn off the dispenser to reset. \\
\hline GROSS LINE FAIL & Alarm & $\begin{array}{l}3.0 \mathrm{gph} \text { line test failure. } \\
\text { Dispensing halts while the } \\
\text { alarm is active. }\end{array}$ & $\begin{array}{l}\text { Turn of dispensing nozzles. } \\
\text { Sec the Leak Verification } \\
\text { Procedure on page } 159 \text { to verify } \\
\text { the leak. }\end{array}$ \\
\hline $\begin{array}{l}\text { HIGH PRESSURE } \\
\text { ALARM }\end{array}$ & Alarm & $\begin{array}{l}\text { Line leak detector components } \\
\text { are not functioning properly. } \\
\text { (Shuts off pump.) }\end{array}$ & $\begin{array}{l}\text { Call for service following the } \\
\text { procedures established for your } \\
\text { site. }\end{array}$ \\
\hline $\begin{array}{l}\text { HIGH PRESSURE } \\
\text { WARN }\end{array}$ & Warning & $\begin{array}{l}\text { The pressure relief components } \\
\text { in the } x \text { are not functioning } \\
\text { properly. }\end{array}$ & $\begin{array}{l}\text { Call for service following the } \\
\text { procedures established for your } \\
\text { site. }\end{array}$ \\
\hline
\end{tabular}


Table 14: Wireless Pressurized Line Leak Detector Status Indicators (Continued)

\begin{tabular}{|c|c|c|c|}
\hline Display Message & $\begin{array}{l}\text { Front Panel } \\
\text { Indicator }\end{array}$ & Cause & Action \\
\hline $\begin{array}{l}\text { PRECISION LINE } \\
\text { FAIL }\end{array}$ & Alarm & $\begin{array}{l}0.20 \mathrm{gph} \text { line test failure. } \\
\text { Dispensing halts while the } \\
\text { alarm is active (only if system } \\
\text { was programmed to shut down } \\
\text { for a } 0.20 \mathrm{gph} \text { leak). }\end{array}$ & $\begin{array}{l}\text { Turn of dispensing nozzles. } \\
\text { See the Leak Verification } \\
\text { Procedure on page } 159 \text { to verily } \\
\text { the leak. }\end{array}$ \\
\hline $\begin{array}{l}\text { WPLLD } \\
\text { PERIODIC WARN }\end{array}$ & Warning & $\begin{array}{l}\text { The system failed to perform a } \\
0.20 \text { gph (periodic) test in the } \\
\text { programmed number of days. } \\
\text { The number of days is set up in } \\
\text { "Periodic Test Wamings," } \\
\text { System Setup menu. } \Lambda 0.20 \mathrm{gph} \\
\text { test must pass to clear the alarm. }\end{array}$ & $\begin{array}{l}\text { See the Leak Verilication } \\
\text { Procedure on page } 159 \text { to verify } \\
\text { the leak. }\end{array}$ \\
\hline $\begin{array}{l}\text { WPLLD } \\
\text { PERIODIC ALARM }\end{array}$ & Alarm & $\begin{array}{l}\text { System fails to perform a } 0.20 \\
\text { gph (periodic) test in the } \\
\text { programmed number of days. } \\
\text { The number of days is set up in } \\
\text { "Periodic Test Warnings," } \\
\text { System Setup menu. Dispensing } \\
\text { halts. A } 0.20 \text { gph test must pass } \\
\text { to clear the alarm. }\end{array}$ & $\begin{array}{l}\text { See the Leak Verification } \\
\text { Procedure on page } 159 \text { to verily } \\
\text { the leak. }\end{array}$ \\
\hline $\begin{array}{l}\text { WPLLD OPEN } \\
\text { ALARM }\end{array}$ & Alarm & $\begin{array}{l}\text { WPLLD disconnected or is not } \\
\text { functioning properly. A } 3.0 \mathrm{gph} \\
\text { test must pass to clear the alarm. }\end{array}$ & $\begin{array}{l}\text { Call for service following the } \\
\text { procedures established for your } \\
\text { site. }\end{array}$ \\
\hline $\begin{array}{l}\text { WPLLD } \\
\text { SHUTDOWN } \\
\text { ALARM }\end{array}$ & Alarm & $\begin{array}{l}\text { WPLLD has shut down. Alarm } \\
\text { is cleared when alarm that } \\
\text { caused the shutdown has } \\
\text { cleared ( } 3.0 \text { gph line test, } 0.20 \\
\text { gph line test, } 0.10 \mathrm{gph} \text { line test, } \\
\text { open alarm, or conm alam). If } \\
\text { the alarm was caused by a } \\
\text { condition that disables } \\
\text { dispensing, "Start WPLLD Line } \\
\text { Test" appears in the display and } \\
\text { the test begins. }\end{array}$ & $\begin{array}{l}\text { Call for service following the } \\
\text { procedures established for your } \\
\text { site. }\end{array}$ \\
\hline $\begin{array}{l}\text { WPLLD COMM } \\
\text { ALARM }\end{array}$ & Alarm & $\begin{array}{l}\text { Communications distupled } \\
\text { between the system and } \\
\text { WPLLD communications } \\
\text { board. Alarm is cleared when } \\
\text { communication resumes. }\end{array}$ & $\begin{array}{l}\text { Call for service following the } \\
\text { procedures established for your } \\
\text { site. }\end{array}$ \\
\hline $\begin{array}{l}\text { CONTINUOUS } \\
\text { PUMP WRN }\end{array}$ & Warning & $\begin{array}{l}\text { Pump has been running for } 8 \\
\text { hours. }\end{array}$ & Turn off the dispenser to reset. \\
\hline $\begin{array}{l}\text { CONTINUOUS } \\
\text { PUMP ALARM }\end{array}$ & Alarm & $\begin{array}{l}\text { Pump has been rumning for } 16 \\
\text { hours. }\end{array}$ & $\begin{array}{l}\text { This alam shuts down the line. } \\
\text { Call for service following the } \\
\text { procedures established for your } \\
\text { site. }\end{array}$ \\
\hline
\end{tabular}


Table 15: $\quad$ Volumetric Line Leak Detector Status Indicators

\begin{tabular}{|c|c|c|c|}
\hline Display Message & Front Panel Indicator & Cause & Action \\
\hline $\begin{array}{l}\text { VLLD SELF TEST } \\
\text { FAIL }\end{array}$ & Alarm & $\begin{array}{l}\text { Line Leak Detector hardware } \\
\text { railure. }\end{array}$ & $\begin{array}{l}\text { Call for service following the } \\
\text { procedures established for your } \\
\text { site. }\end{array}$ \\
\hline $\begin{array}{l}\text { LINE LEAK } \\
\text { SHUTDOWN }\end{array}$ & Alarm & $\begin{array}{l}\text { Line test or pumpside test } \\
\text { failure. }\end{array}$ & $\begin{array}{l}\text { Call for service following the } \\
\text { procedures established for your } \\
\text { site. }\end{array}$ \\
\hline $\begin{array}{l}\text { LINE LEAK TEST } \\
\text { FAIL }\end{array}$ & Alarm & $\begin{array}{l}\text { Line Test or Pumpside Test } \\
\text { Failure. }\end{array}$ & $\begin{array}{l}\text { Call for service following the } \\
\text { procedures established for your } \\
\text { site. }\end{array}$ \\
\hline $\begin{array}{l}\text { SELF TEST } \\
\text { INVALID }\end{array}$ & Warning & $\begin{array}{l}\Lambda \text { self-test failure during a } \\
\text { requested test has occurred. }\end{array}$ & $\begin{array}{l}\text { Run the same test again. If the } \\
\text { system fails, call for service } \\
\text { following the procedures } \\
\text { established for your site. }\end{array}$ \\
\hline $\begin{array}{l}\text { CONTINUOUS } \\
\text { PUMP WRN }\end{array}$ & Warning & $\begin{array}{l}\text { The pump has not turned off for } \\
2 \text { hours. }\end{array}$ & $\begin{array}{l}\text { Call for service following the } \\
\text { procedures established for your } \\
\text { site. }\end{array}$ \\
\hline $\begin{array}{l}\text { GRS LINE TEST } \\
\text { FAIL }\end{array}$ & Alarm & $\begin{array}{l}3.0 \text { gph line test failure. (Three } \\
\text { consecutive self-test failures.) }\end{array}$ & $\begin{array}{l}\text { Call for service following the } \\
\text { procedures established for your } \\
\text { site. }\end{array}$ \\
\hline $\begin{array}{l}\text { GRS LINE SELF } \\
\text { FAIL }\end{array}$ & Alarm & $3.0 \mathrm{gph}$ line self-test failure. & $\begin{array}{l}\text { Run the same test again. If the } \\
\text { system fails, call for service } \\
\text { following the procedures } \\
\text { established for your site. }\end{array}$ \\
\hline $\begin{array}{l}\text { GRS PUMP TEST } \\
\text { FAIL }\end{array}$ & Alarm & $3.0 \mathrm{gph}$ pumpside test failure. & $\begin{array}{l}\text { Run the same test again. If the } \\
\text { system fails, call for service } \\
\text { following the procedures } \\
\text { established for your site. }\end{array}$ \\
\hline $\begin{array}{l}\text { GRS PUMP SELF } \\
\text { FAIL }\end{array}$ & Alarm & $\begin{array}{l}3.0 \text { gph pumpside self-test } \\
\text { failure. }\end{array}$ & $\begin{array}{l}\text { Run the same test again. If the } \\
\text { system fails, call lor service } \\
\text { following the procedures } \\
\text { established for your site. }\end{array}$ \\
\hline $\begin{array}{l}\text { VLLD PERIODIC } \\
\text { WARN }\end{array}$ & Warning & $\begin{array}{l}\text { The system failed to perform a } \\
0.20 \text { gph (periodic) test in the } \\
\text { programmed number of days. }\end{array}$ & $\begin{array}{l}\text { Call for service following the } \\
\text { procedures established for your } \\
\text { site. }\end{array}$ \\
\hline $\begin{array}{l}\text { VLLD PERIODIC } \\
\text { ALARM }\end{array}$ & Alarm & $\begin{array}{l}\text { The system failed to perform a } \\
0.20 \text { gph (periodic) test in the } \\
\text { programmed number of days. }\end{array}$ & $\begin{array}{l}\text { Call for service following the } \\
\text { procedures established for your } \\
\text { site. }\end{array}$ \\
\hline $\begin{array}{l}\text { VLLD ANNUAL } \\
\text { WARNING }\end{array}$ & Warning & $\begin{array}{l}\text { The system fails to perform a } \\
0.10 \text { gph (annual) test in the } \\
\text { programmed number of days. }\end{array}$ & $\begin{array}{l}\text { Call for service following the } \\
\text { procedures established for your } \\
\text { site. }\end{array}$ \\
\hline
\end{tabular}


Table 15: Volumetric Line Leak Detector Status Indicators (Continued)

\begin{tabular}{|c|c|c|c|}
\hline Display Message & Front Panel Indicator & Cause & Action \\
\hline $\begin{array}{l}\text { VLLD ANNUAL } \\
\text { ALARM }\end{array}$ & Alarm & $\begin{array}{l}\text { The system fails to perform a } \\
0.10 \text { gph (annual) test in the } \\
\text { programmed number of days. }\end{array}$ & $\begin{array}{l}\text { Call for service following the } \\
\text { procedures cstablished for your } \\
\text { site. }\end{array}$ \\
\hline $\begin{array}{l}\text { PER-LINE TEST } \\
\text { FAIL }\end{array}$ & Alarm & $\begin{array}{l}0.20 \text { gph line test failure. (Two } \\
\text { consecutive self-test failures.) }\end{array}$ & $\begin{array}{l}\text { Run the } 0.20 \text { gph test again. If } \\
\text { the system fails, call for service } \\
\text { following the procedures } \\
\text { established for your site. }\end{array}$ \\
\hline $\begin{array}{l}\text { PER-LINE SELF } \\
\text { FAlL }\end{array}$ & Alarm & $0.20 \mathrm{gph}$ line self-test failure. & $\begin{array}{l}\text { Run the } 0.20 \text { gph test again. If } \\
\text { the system fails, call for service } \\
\text { following the procedures } \\
\text { established for your site. }\end{array}$ \\
\hline $\begin{array}{l}\text { PER-PUMP TEST } \\
\text { FAIL }\end{array}$ & Alarm & 0.20 gph pumpside test failure. & $\begin{array}{l}\text { Run the } 0.20 \text { gph test again. If } \\
\text { the system fails, call for service } \\
\text { following the procedures } \\
\text { established for your site. }\end{array}$ \\
\hline $\begin{array}{l}\text { PER-PUMP SELF } \\
\text { FAIL }\end{array}$ & Alarm & $\begin{array}{l}0.20 \text { gph pumpside self-test } \\
\text { failure. }\end{array}$ & $\begin{array}{l}\text { Run the } 0.20 \text { gph test again. If } \\
\text { the system fails, call for service } \\
\text { following the procedures } \\
\text { cstablished for your site. }\end{array}$ \\
\hline $\begin{array}{l}\text { ANN-LINE TEST } \\
\text { FAIL }\end{array}$ & Alarm & $0.10 \mathrm{gph}$ line test failure. & $\begin{array}{l}\text { Call for service following the } \\
\text { procedures established lor your } \\
\text { sitc. }\end{array}$ \\
\hline $\begin{array}{l}\text { ANN-LINE SELF } \\
\text { FAIL }\end{array}$ & Alarm & $\begin{array}{l}0.10 \mathrm{gph} \text { line self-test failure. } \\
\text { (Two consecutive self-test } \\
\text { failures.) }\end{array}$ & $\begin{array}{l}\text { Call for service following the } \\
\text { procedures established for your } \\
\text { site. }\end{array}$ \\
\hline $\begin{array}{l}\text { ANN-PUMP TEST } \\
\text { FAIL }\end{array}$ & Alarm & $0.10 \mathrm{gph}$ Pumpside Test failure. & $\begin{array}{l}\text { Call for service following the } \\
\text { procedures established for your } \\
\text { site. }\end{array}$ \\
\hline $\begin{array}{l}\text { ANN-PUMP SELF } \\
\text { FAIL }\end{array}$ & $\Lambda \mathrm{larm}$ & $\begin{array}{l}0.10 \text { gph pumpside self-test } \\
\text { failure. }\end{array}$ & $\begin{array}{l}\text { Call for service following the } \\
\text { procedures established for your } \\
\text { site. }\end{array}$ \\
\hline $\begin{array}{l}\text { VLLD PRESSURE } \\
\text { WARN }\end{array}$ & Warning & $\begin{array}{l}\text { Three consecutive allempts to } \\
\text { run a test in which the pressure } \\
\text { switch never opened (pump not } \\
\text { running). }\end{array}$ & $\begin{array}{l}\text { Call for service following the } \\
\text { procedures established for your } \\
\text { site. }\end{array}$ \\
\hline $\begin{array}{l}\text { VLLD PRESSURE } \\
\text { ALARM }\end{array}$ & Alarm & $\begin{array}{l}\text { Six consecutive attempts to run } \\
\text { a test in which the pressure } \\
\text { switch never opened (pump not } \\
\text { running). }\end{array}$ & $\begin{array}{l}\text { Call for service following the } \\
\text { procedures established for your } \\
\text { site. }\end{array}$ \\
\hline FUEL OUT & Alarm & $\begin{array}{l}\text { Product level below } 10 \text { inches } \\
\text { and three consecutive } 3.0 \mathrm{gph} \\
\text { self-test failures. }\end{array}$ & Call for delivery. \\
\hline
\end{tabular}


Table 15: Volumetric Line Leak Detector Status Indicators (Continued)

\begin{tabular}{|c|c|c|c|}
\hline Display Message & Front Panel Indicator & Cause & Action \\
\hline $\begin{array}{l}\text { VLLD TEST FAULT } \\
\text { - GRS }\end{array}$ & Alarm & $\begin{array}{l}\text { Line leak detector hardware } \\
\text { failure }\end{array}$ & $\begin{array}{l}\text { Call for service following the } \\
\text { procedures established for your } \\
\text { site. }\end{array}$ \\
\hline $\begin{array}{l}\text { VLLD TEST FAULT } \\
\text { - PER }\end{array}$ & Alarm & $\begin{array}{l}\text { Line leak detector hardware } \\
\text { failure }\end{array}$ & $\begin{array}{l}\text { Call for service following the } \\
\text { procedures established for your } \\
\text { site. }\end{array}$ \\
\hline $\begin{array}{l}\text { VLLD TEST FAULT } \\
\text { - ANN }\end{array}$ & Alarm & $\begin{array}{l}\text { Line leak detector lardware } \\
\text { failure }\end{array}$ & $\begin{array}{l}\text { Call for service following the } \\
\text { procedures established for your } \\
\text { site. }\end{array}$ \\
\hline $\begin{array}{l}\text { TEST CURRENTLY } \\
\text { ON HOLD }\end{array}$ & None & $\begin{array}{l}3.0 \text { gph self-test failure or } \\
\text { VLLD PRESSURE WARN } \\
\text { alarm. }\end{array}$ & $\begin{array}{l}\text { Retest to validate outcome on } \\
\text { next dispense. } \wedge \text { fter } 3 \text { rd } \\
\text { oceurrence, system will alarm. } \\
\text { After } 6 \text { th occurrence, system } \\
\text { will shut down. }\end{array}$ \\
\hline
\end{tabular}

Table 16: Groundwater Sensor Status Indicators

\begin{tabular}{|l|l|l|l|}
\hline \multicolumn{1}{|c|}{ Display Message } & Front Panel Indicator & \multicolumn{1}{|c|}{ Cause } & \multicolumn{1}{|c|}{ Action } \\
\hline \hline FUEL ALARM & Alarm & $\begin{array}{l}\text { A groundwater sensor in an } \\
\text { observation well detects fuel. }\end{array}$ & $\begin{array}{l}\text { Call for service following the } \\
\text { procedures established for } \\
\text { your site. }\end{array}$ \\
\hline $\begin{array}{l}\text { WATER OUT } \\
\text { ALARM }\end{array}$ & Warning & $\begin{array}{l}\text { Water level is below the float } \\
\text { switch making the groundwater } \\
\text { sensor ineffective. }\end{array}$ & $\begin{array}{l}\text { Call for scrvice following the } \\
\text { procedures established for } \\
\text { your site. }\end{array}$ \\
\hline $\begin{array}{l}\text { SENSOR OUT } \\
\text { ALARM }\end{array}$ & Alarm & $\begin{array}{l}\text { The sensor is disconnected or is } \\
\text { not functioning properly. }\end{array}$ & $\begin{array}{l}\text { Call for service following the } \\
\text { procedures established for } \\
\text { your site. }\end{array}$ \\
\hline SHORT ALARM & Alarm & $\begin{array}{l}\text { An internal short has occurred in } \\
\text { the sensor. }\end{array}$ & $\begin{array}{l}\text { Call for service following the } \\
\text { procedures cstablished for } \\
\text { your site. }\end{array}$ \\
\hline
\end{tabular}


Table 17: 2-Wire C.L. Discriminating Interstitial Sensor Status Indicators

\begin{tabular}{|l|l|l|l|}
\hline \multicolumn{1}{|c|}{ Display Message } & \multicolumn{1}{|c|}{ Front Panel Indicators } & \multicolumn{1}{|c|}{ Cause } & \multicolumn{1}{|c|}{ Action } \\
\hline FUEL ALARM & Alarm & A sensor has detected fuel. & $\begin{array}{l}\text { Call for service following } \\
\text { lhe procedures established } \\
\text { for your site. }\end{array}$ \\
\hline WATER ALARM & Warning & A sensor has delected water. & $\begin{array}{l}\text { Call for service following } \\
\text { the procedures established } \\
\text { for your site. }\end{array}$ \\
\hline $\begin{array}{l}\text { SENSOR OUT } \\
\text { ALARM }\end{array}$ & Alarm & $\begin{array}{l}\text { The sensor is disconnected or is } \\
\text { not functioning properly. }\end{array}$ & $\begin{array}{l}\text { Call for service following } \\
\text { the procedures established } \\
\text { for your sitc. }\end{array}$ \\
\hline SHORT ALARM & Alarm & $\begin{array}{l}\text { An internal short has occurred } \\
\text { in the sensor. }\end{array}$ & $\begin{array}{l}\text { Call for service following } \\
\text { the procedures established } \\
\text { for your sitc. }\end{array}$ \\
\hline
\end{tabular}

Table 18: 2-Wire C.L. Discriminating Interstitial Micro Sensor Status Indicators

\begin{tabular}{|l|l|l|l|}
\hline \multicolumn{1}{|c|}{ Display Message } & \multicolumn{1}{|c|}{$\begin{array}{c}\text { Front Panel } \\
\text { Indicator }\end{array}$} & \multicolumn{1}{|c|}{ Cause } & \multicolumn{1}{c|}{ Action } \\
\hline \hline SHORT ALARM & Alarm & $\begin{array}{l}\text { An internal short has occurred } \\
\text { in the sensor. }\end{array}$ & $\begin{array}{l}\text { Call for service following the } \\
\text { procedures established for your } \\
\text { site. }\end{array}$ \\
\hline FUEL ALARM & Alarm & $\begin{array}{l}\text { Liquid is present in the area } \\
\text { being monitored by the sensor. }\end{array}$ & $\begin{array}{l}\text { Inmediately follow the alarm } \\
\text { teporting procedures established } \\
\text { for your site. }\end{array}$ \\
\hline \multirow{2}{*}{$\begin{array}{l}\text { SENSOR OUT } \\
\text { ALARM }\end{array}$} & Alarm & $\begin{array}{l}\text { The sensor is disconnected or } \\
\text { is not functioning properly. }\end{array}$ & $\begin{array}{l}\text { Sensor problem must be cor- } \\
\text { rected or sensor replaced. Call } \\
\text { for service following the proce- } \\
\text { dures established for your site. }\end{array}$ \\
\cline { 2 - 4 } & $\begin{array}{l}\text { Liquid Sensor selup was per- } \\
\text { formed incorrectly. }\end{array}$ & $\begin{array}{l}\text { Reenter this liquid sensor's sctup } \\
\text { values. }\end{array}$ \\
\hline
\end{tabular}


Table 19: 3-Wire C.L. Sensor Status Indicators

\begin{tabular}{|c|c|c|c|}
\hline FUEL ALARM & Alarm & $\begin{array}{l}\Lambda \text { dispenser pan or containment } \\
\text { sump sensor has detected fuel. }\end{array}$ & $\begin{array}{l}\text { Call for service following the } \\
\text { procedures established for } \\
\text { your site. }\end{array}$ \\
\hline $\begin{array}{l}\text { HIGH LIQUID } \\
\text { ALARM }\end{array}$ & Alarm & $\begin{array}{l}\text { A scmsor detects a high liquid } \\
\text { level. }\end{array}$ & $\begin{array}{l}\text { Call for service following the } \\
\text { procedures established for } \\
\text { your site. }\end{array}$ \\
\hline LIQUID WARNING & ヘlarm & $\begin{array}{l}\text { A sensor detects a small } \\
\text { amount of licpuid. }\end{array}$ & $\begin{array}{l}\text { Call for service following the } \\
\text { procedures established for } \\
\text { your site. }\end{array}$ \\
\hline $\begin{array}{l}\text { SENSOR OUT } \\
\text { ALARM }\end{array}$ & Alarm & $\begin{array}{l}\text { The sensor is disconnected or is } \\
\text { not functioning properly. }\end{array}$ & $\begin{array}{l}\text { Call for service following the } \\
\text { procedures established for } \\
\text { your site. }\end{array}$ \\
\hline
\end{tabular}

Table 20: External Input Messages

\begin{tabular}{|l|l|l|l}
\hline \multicolumn{1}{|c|}{ Display Message } & \multicolumn{1}{|c|}{$\begin{array}{c}\text { Front Panel } \\
\text { Indicator }\end{array}$} & Cause & Action \\
\hline $\begin{array}{l}\text { EXTERNAL INPUT } \\
\text { ALARM }\end{array}$ & Alarm & $\begin{array}{l}\text { External device changed from } \\
\text { preset condition. }\end{array}$ & $\begin{array}{l}\text { Check the operation of the } \\
\text { external device. }\end{array}$ \\
\hline $\begin{array}{l}\text { GENERATOR ON } \\
\text { (In emergency } \\
\text { generator } \\
\text { applications only.) }\end{array}$ & None & $\begin{array}{l}\text { Backup generator went ontine, in- } \\
\text { tank leak testing halted. }\end{array}$ & Wait until power is restorcd. \\
\hline $\begin{array}{l}\text { GENERATOR OFF } \\
\text { (In emergency } \\
\text { generator } \\
\text { applications only.) }\end{array}$ & None & $\begin{array}{l}\text { Backup generator shut down, in- } \\
\text { tank leak testing resumed. }\end{array}$ & None. \\
\hline
\end{tabular}


Table 21: Business Inventory Reconciliation (BIR) Messages*

\begin{tabular}{|c|c|c|c|}
\hline Display Message & Front Panel Indicator & Cause & Action \\
\hline $\begin{array}{l}\text { CLOSE SHIFT } \\
\text { PENDING }\end{array}$ & Warning & $\begin{array}{l}\text { The system is waiting for an } \\
\text { idle period to close for a shift } \\
\text { report. }\end{array}$ & $\begin{array}{l}\text { System clears itself after idle } \\
\text { period and shift closes. }\end{array}$ \\
\hline $\begin{array}{l}\text { CLOSE DAILY } \\
\text { PENDING }\end{array}$ & Warning & $\begin{array}{l}\text { The system is waiting for an } \\
\text { idle period to close for a daily } \\
\text { shift report. }\end{array}$ & $\begin{array}{l}\text { System clears itself after idle } \\
\text { period and shift closes. }\end{array}$ \\
\hline $\begin{array}{l}\text { PROD } \\
\text { THRESHOLD ALM }\end{array}$ & Alarm & $\begin{array}{l}\text { The variance exceded the } \\
\text { calculated threshold for the } \\
\text { periodic report. }\end{array}$ & $\begin{array}{l}\text { Press the Alarm/Test key to } \\
\text { acknowledge the alarm and } \\
\text { clear the display. }\end{array}$ \\
\hline $\begin{array}{l}\text { DISABLED DIM } \\
\text { ALARM }\end{array}$ & Alarm & $\begin{array}{l}\text { No communication between } \\
\text { ECPU board and DIM board. }\end{array}$ & $\begin{array}{l}\text { Call for service following the } \\
\text { procedures established for } \\
\text { your site. }\end{array}$ \\
\hline $\begin{array}{l}\text { COMMUNICATION } \\
\text { ALARM }\end{array}$ & Alarm & $\begin{array}{l}\text { No communication between } \\
\text { DIM board and an external } \\
\text { device. }\end{array}$ & $\begin{array}{l}\text { Call for service following the } \\
\text { procedures established for } \\
\text { your site. }\end{array}$ \\
\hline
\end{tabular}

* TLS-350R only 


\section{Appendix B: State of Washington Summary of Requirements for USTs, Publication No. 94-32}

Summary of Requirements for Underground Storage Tanks:

Release Detection

Corrosion Protection Spill/Overfill Prevention

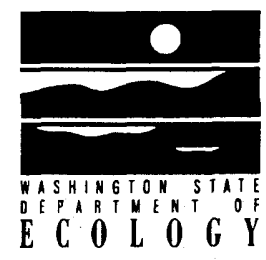

These tables summarize portions of the Washington State Underground Storage Tank Regulations (Chapter 173-360 WAC). For more information consult the regulations or call the Department of Ecology at one of the number listed inside. 


\section{WHAT DO YOU HAVE TO DO?} Minimum Requirements

"NEW" tanks and piping are those installed after December 1988.

"EXISTING" tanks and piping are those installed before December 1988.

\begin{tabular}{|c|c|}
\hline RELEASP DETECTION & W \\
\hline $\begin{array}{l}\text { NEW TANKS } \\
2 \text { Cholces }\end{array}$ & $\begin{array}{l}\text { - Monthly Monitoring' } \\
\text { - Daily Inventory Control and Tank Tightness Testing Every } 5 \text { Years } \\
\text { (You can only use this choice for } 10 \text { years after installation.) })^{2}\end{array}$ \\
\hline $\begin{array}{l}\text { EXISTING TANKS } \\
3 \text { Cholces }\end{array}$ & $\begin{array}{l}\text { - Monthly Monitoring' } \\
\text { - Daily Inventory Control and Annual Tank Tightness Testing } \\
\text { (This choice can only be used untll December 1998.) } \\
\text { - Daily Inventory Control and Tank Tightness Testing Every } 5 \text { Years } \\
\text { (This choice can only be used for } 10 \text { years after adding corrosion protection } \\
\text { and spill/overtill prevention or until December 1998, whichever date is tater.) }\end{array}$ \\
\hline $\begin{array}{l}\text { NEW \& EXISTING } \\
\text { PRESSURIZED PIPING } \\
\text { Must have one from each set }\end{array}$ & $\begin{array}{l}\text { - Automatic Flow Restrictor } \\
\text { - Automatic Shutoff Device and - Monthly Monitoring } \\
\text { - Continuous Alarm System }\end{array}$ \\
\hline $\begin{array}{l}\text { NEW \& EXISTING } \\
\text { SUCTION PIPING } \\
3 \text { Cholces }\end{array}$ & $\begin{array}{l}\text { - Monthly Monitoring, } \\
\text { - Line Testing Every } 3 \text { Years } \\
\text { - No Requirements if piping meets certain conditions }{ }^{4}\end{array}$ \\
\hline \multicolumn{2}{|l|}{ CORROSION PROTECTION } \\
\hline $\begin{array}{l}\text { NEW TANKS } \\
3 \text { Cholces }\end{array}$ & $\begin{array}{l}\text { - Coated and Cathodically Protected Steel } \\
\text { - Fiberglass } \\
\text { - Steel Tank Clad with Fiberglass (Composite) }\end{array}$ \\
\hline $\begin{array}{l}\text { EXISTING TANKS } \\
4 \text { Choices }\end{array}$ & $\begin{array}{l}\text { - Same Options as for New Tanks } \\
\text { - Add Cathodic Protection System } \\
\text { - Interior Lining } \\
\text { - Interior Lining and Cathodic Protection }\end{array}$ \\
\hline $\begin{array}{l}\text { NEW PIPING } \\
2 \text { Cholces }\end{array}$ & $\begin{array}{l}\text { - Coated and Cathodically Protected Steel } \\
\text { - Fiberglass }\end{array}$ \\
\hline $\begin{array}{l}\text { EXISTING PIPING } \\
2 \text { Cholces }\end{array}$ & $\begin{array}{l}\text { - Same Options as for New Piping } \\
\text { - Cathodically Protected Steel }\end{array}$ \\
\hline \multicolumn{2}{|c|}{ SPIL YOYERFIL PREVENTION } \\
\hline ALL TANKS & $\begin{array}{l}\text { - Automatic Shutoff Device or } \\
\text { - Overfill Alarm or } \\
\text { - Ball Float Valve }\end{array}$ \\
\hline
\end{tabular}

'Monthly monltoring methods for tanks include Automatic Tank Gauging. Vapor Monitoring, Interstitial Monltoring. Ground Water Monltoring and other approved methods.

${ }^{2} T a n k s$ under 2000 gallons may also be able to use weekly tank gauging (see WAC 173-360-345).

${ }^{3}$ Monthly monitoring methods for piping do not include Automatic Tank Gauging.

${ }^{4}$ Only one check valve which is located directly below the dispenser and piping is sloped towards the tank. 


\section{WHEN DO YOU HAVE TO ACT?}

\section{Important Deadlines}

"NEW" tanks and piping are those Installed after December 1988.

"EXISTING" tanks and plping are those installed before December 1988.

\begin{tabular}{|c|c|c|c|}
\hline 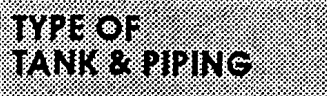 & MEIFHW OHOH. & $\% \% \% 1 \%$ & 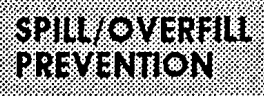 \\
\hline New Tanks and Piping & At installation & At installation & At installation \\
\hline $\begin{array}{l}\text { Existing Tanks' } \\
\text { Installed: } \\
\text { Before } 1965 \text { or unknown } \\
1965-1969 \\
1970-1974 \\
1975-1979 \\
1980 \text { - December } 1988\end{array}$ & $\begin{array}{l}\text { By No Later Than: } \\
\text { December } 1989 \\
\text { December } 1990 \\
\text { December } 1991 \\
\text { December } 1992 \\
\text { December } 1993\end{array}$ & December 1998 & December 1998 \\
\hline $\begin{array}{l}\text { Existing Piping } \\
\text { Pressurized Piping } \\
\text { Suction Piping }\end{array}$ & $\begin{array}{l}\text { December } 1990 \\
\text { If required, same as } \\
\text { existing tanks }\end{array}$ & $\begin{array}{l}\text { December } 1998 \\
\text { December } 1998\end{array}$ & $\begin{array}{l}\text { Does not apply } \\
\text { Does not apply }\end{array}$ \\
\hline
\end{tabular}

'Deadlines for release detection on emergency power generator tanks are extended two years beyond this schedule (1.e., such tanks installed in 1970-1974 must have release detection by December 1993, rather than $1991, \theta$ etc.).

Who can you call for more information?

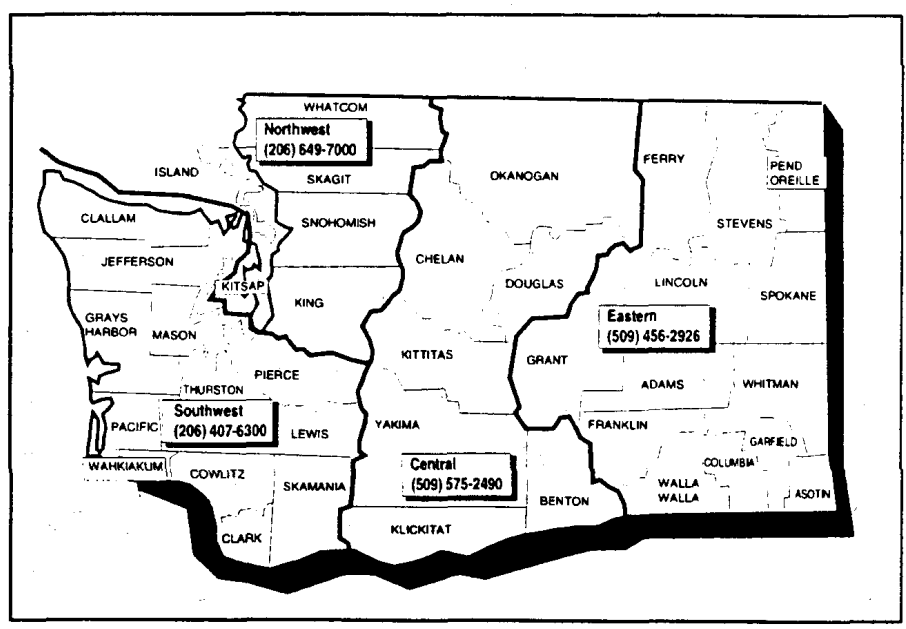




\section{CERL Distribution}

Fort Lewis, WA

ATTN: AFZH-DWS-RNB (2)

Chief of Engineers

ATTN: CEHEC-IM-LH (2)

ATTN: HECSA Mailroom (2)

ATTN: CECC-R

Engineer Research and Development Center (Libraries)

ATTN: ERDC, Vicksburg, MS

ATTN: Cold Regions Research, Hanover, NH

ATTN: Topographic Engineering Center, Alexandria, VA

Defense Tech Info Center 22304

ATTN: DTIC-O

11

$3 / 01$ 


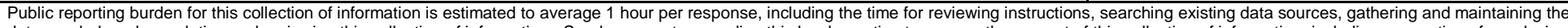

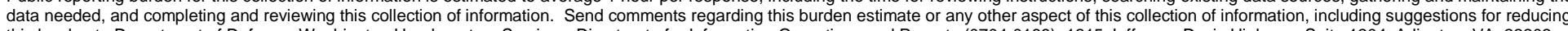

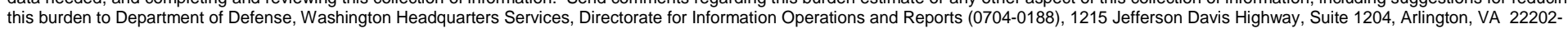

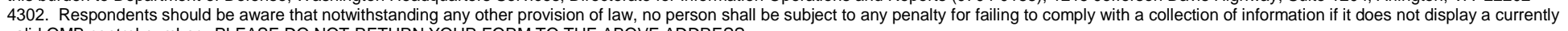
valid OMB control number. PLEASE DO NOT RETURN YOUR FORM TO THE ABOVE ADDRESS.
1. REPORT DATE (DD-MM-YYYY)
03-2001
2. REPORT TYPE
Final

4. TITLE AND SUBTITLE

Management System for Fluid Storage Tanks at Fort Lewis, WA

3. DATES COVERED (From - To)

5a. CONTRACT NUMBER

5b. GRANT NUMBER

5c. PROGRAM ELEMENT NUMBER

6. AUTHOR(S)

Jearldine I. Northrup, Joyce C. Baird, Donald J. Schiller, and James F. Lee

5d. PROJECT NUMBER

MIPR

5e. TASK NUMBER

5f. WORK UNIT NUMBER

0CCERL3012

7. PERFORMING ORGANIZATION NAME(S) AND ADDRESS(ES)

U.S. Army Engineer Research and Development Center (ERDC)

8. PERFORMING ORGANIZATION REPORT

Construction Engineering Research Laboratory (CERL)

NUMBER

ERDC/CERL TR-01-27

P.O. Box 9005

Champaign, IL 61826-9005

\section{SPONSORING / MONITORING AGENCY NAME(S) AND ADDRESS(ES)}

Fort Lewis

P.O. Box 339500

Fort Lewis, WA 98433-9500

10. SPONSOR/MONITOR'S ACRONYM(S)

AFZH-DWS-RMB

11. SPONSOR/MONITOR'S REPORT NUMBER(S)

\section{DISTRIBUTION / AVAILABILITY STATEMENT}

Approved for public release; distribution is unlimited.

\section{SUPPLEMENTARY NOTES}

Copies are available from the National Technical Information Service, 5285 Port Royal Road, Springfield, VA 22161.

\section{ABSTRACT}

Fort Lewis Military Reservation is a large Army installation located in western Washington State. Some of the organizations at Fort Lewis require the use of hazardous substances and generate hazardous waste. The U.S. Army Engineer Research and development Center (ERDC), Construction Engineering Research Laboratory (CERL) was tasked with electronically consolidating fluid storage tank information for underground storage tanks (USTs) and aboveground storage tanks (ASTs) at Fort Lewis. This work performed the first of three steps to monitor storage tanks at Fort Lewis by demonstrating an integrated storage tank monitoring system of limited scope. Later work will assess methods to connect all regulated tanks to the monitoring system computer, and a third task will connect as many of the remaining unregulated tanks to the monitoring system as possible.

\section{SUBJECT TERMS}

Fort Lewis, WA

underground storage tanks (UST)

16. SECURITY CLASSIFICATION OF:

a. REPORT

Unclassified b. ABSTRACT

Unclassified aboveground storage tanks (AST)

waste management alarm system

monitoring

\begin{tabular}{|c|c|c|}
\hline & $\begin{array}{l}\text { 17. LIMITATION } \\
\text { OF ABSTRACT }\end{array}$ & $\begin{array}{l}\text { 18. NUMBER } \\
\text { OF PAGES }\end{array}$ \\
\hline $\begin{array}{l}\text { c. THIS PAGE } \\
\text { Unclassified }\end{array}$ & SAR & 40 \\
\hline
\end{tabular}

19a. NAME OF RESPONSIBLE PERSON
Jearldine I. Northrup
$\begin{aligned} & \text { 19b. TELEPHONE NUMBER (in- } \\ & \text { clude area code) } \\ & \text { (217) } 373-4472\end{aligned}$ 